ARTICLE HISTORY: Received: August 19, 2021 Accepted: October 12, 2021 Published: October 19, 2021

\title{
LIBERATION AND EMPOWERMENT OR DEBAUCHERY AND EMBOLDENED, IN ANTHROPOECOLOGY
}

\author{
Leonel Chacon Anchondo \\ Industrial Engineer, Technological Institute Cd. Juárez \\ Cd. Cuauhtémoc, Chihuahua, Mexico, Tepeyac street \# 4030, 31520
}

\begin{abstract}
From first writings, a suspiciousness of women is shown towards where the relationship between woman and man (Eve and Adam) is directed. A great historian said: "as soon as women begin to be equal, they will be superior", [Tito Livio, 59 BC. - 17 AD.]. And it is precisely there the error, woman and man, are not equal, each one has its qualities to complement each other, but unfortunately, they have been used to compete for a power that no one can maintain, but it destroys relationships and societies. These sometimes pendular behaviors are contextualized from point of view of Anthropoecology.

Feminism is one more current of many there are; Although its purposes are fair and reasonable, it must take care that liberation do not turn into debauchery and empowerment into emboldening, and eliminating millions of femicides that are practiced annually by abortions.

Perhaps due to paradigms of interest or because we have become mentally ill, human being has not taken on the task of identifying and defining the laws of nature that should govern their behavior. Animals instinctively only take what is necessary to live, they do not accumulate. Human being because of his greed, takes more than necessary and accumulates, without obeying natural laws. Human being due to his intellectual qualities, is the most destructive and libertine animal.

Mistakenly, a competition has been created; influenced by some intellectuals and thinkers, where ideas of all kinds of competition originate, unfortunately in a not very positive way, which are disseminated by the media.

Most people say "in this troubled world", excluding themselves from their responsibility for what happen.

Way in which concepts are exposed is with intention of questioning, not attacking, to induce a reflection and a reaction on our wrong attitude, evidenced by undeniable problems that we have as a society and damage caused to environment. Only a positive formative education will correct damage that human beings have inflicted on themselves for millennia.

Keywords: superiors, equals, qualities, complement each other, compete, nature, instinct, suspicion, liberation, empowerment, femicide, abortion, convulsed.
\end{abstract}

\section{CONTEXT OF THE EXISTENCE OF HUMAN BEING, FROM POINT OF VIEW OF ANTHROPOECOLOGY}

By respectfully taking the ideas of other writers and reports, it is not about repeating them; rather, put them in context, from point of view of Anthropoecology.

That is why in this article writings that are believed to be most significant are taken, without underestimating others, some of them having very important contributions.

No one has the absolute truth; this writing is a questioning with intention of showing the pendular behavior and that the manifestations of human being achieve their legitimate objectives for good of all. Avoiding undesirable behaviors, confrontations, and debauchery.

DEFINITION OF ANTHROPOECOLOGY: "It is the dynamic balance in animal, intellectual, social, cultural, spiritual, moral, ethical, economic and politics of human being in conjunction with the environment in which he lives." [Anthropoecology, Leonel Chacon Anchondo].

DEFINITION OF MENTAL ILLNESS: "It is the generation of ideas and attitudes, in thinking, deciding and acting, in a physiologically healthy brain, of human being, whose thoughts position him above other human beings, inflicting damage on majority of cases and obtaining profit for himself. " [Anthropoecology, Leonel Chacon Anchondo.].

CONCENTRATION OF HUMAN BEINGS, ASSOCIATIONS

CONCENTRATION OF HUMAN BEINGS: it originates a number of artificial environments, which generate harmful and surreptitious behaviors and attitudes, making life in cities difficult. And they are very far from anthropoecological balance of human being.

Most atrocious plague that earth has in its millions of years of existence is the being that calls itself "sapiens".

ASSOCIATIONS: it is natural and legitimate to associate, some seek to do common good, others are manipulative and only see their interests and others do intentional damage, they are classist, discriminatory and racist. Due to their characteristics and actions, some associations show that there is non-compliance and manipulation of the laws. The family and the grouping of human beings for coexistence and subsistence are natural associations. 


\section{NIGHTLIFE, ALCOHOLISM AND DRUGS, GANG AND CRIME, NEW NORMS}

NIGHTLIFE: Cities give impression of a relaxed and fun life, creating specific places, due to need for distraction and mating, these places lend themselves to surreptitious activities.

Human coexistence is essential. In small communities, social and family contact is continuous, due to closeness, in these communities everyone knows each other and is supposed to take care of each other. In cities they do not know each other, leading to indifference, individualism and competition.

ALCOHOLISM AND DRUGS: human being is looking through science, in which part of the brain is the stimulation and roots of vices such as alcoholism and drugs, to block these functions and free it from said stimulus. Instead of educating ourselves positively.

The child or adolescent is caught up in drugs, in large part because image of his parents is not present in his mind when drug tempts him. Positive image that child has of his parents is a factor that gives him security and he know that it is due to them; However, when this image is not clear or in the worst case it is negative, then child or adolescent is susceptible to falling into drugs or alcoholism. If drugs accompany child, then they are better company than its parents.

Reality is that drug trafficking is a consequence of drug use, due to social decomposition.

Powerful countries qualify themselves as "high morals" and blame others for their drug addiction problem, when as a general rule and common sense, the first accomplice of drug trafficker is the consumer.

Instead of campaigning to legalize marijuana (21st century AD.), It should be done to achieve a positive formative education. For this education, information already exists, but is ignored day by day.

GANG AND CRIME: sources of crime are many and varied and until these sources are eliminated, crime will prevail over all reasoning.

Gang and crime are found at all levels of society and both genders. White collar offenders typically come from families who classify themselves as "honest, well-educated and very intelligent", but those who receive the punishment of "law" are those from the suburbs.

Historically, human behavior has been more animal than rational due to individualism and greed, even when we know about it, the benefit of voracity is greater than shame and conscience.

NEW NORMS: nature has dictated a series of norms within dynamic equilibrium and that they will never be given in writing to human being; rather, it is his responsibility to write and obey them. These rules have not been obeyed for thousands of years, since human being became mentally ill of greed. Concentration of human beings in cities has caused him to forget natural norms, since artificial environment has led him to establish new norms.

For humanity it is very harmful that men, women and children only demand their criminal, civil and social rights, but avoid their obligations and responsibilities. Human rights are in fashion, but positive formative education.

\section{COMPETITION, SPORTS AND SHOWS, BEAUTY CONTESTS, FILMS AND TELEVISION AWARDS,} SOCIAL STATUS AND INDIVIDUALISM

COMPETITION: it is another environment created by humans. It is perhaps the most inhumane, that goes unnoticed as an environment; Rather, being competitive is considered a virtue.

Subsistence itself is not a competition, it is a routine of life.

In any type of competition, a number of material riches can be obtained except humility. Feminist movement is certainly correct; but. How far is it correct and how far has it become a competition?

It seems that women compete, to see which ones are more liberated (debauchery), which are more empowered (emboldened). Is women seeking her natural security or are some seeking their personal interests?

SPORTS AND SHOWS: for their economic gain, many individuals want to participate in them, because those at top of the pyramid obtain great economic benefits in addition to being admired and in some cases venerated as idols. And when an idol is turned off, it simply another appears.

Media are main promoters in praising "spectacular feats" of athletes and shows, leading children and young people to spend their lives and illusions dreaming of becoming stars, but very few will arrive.

Millionaire salaries of sports and shows are an exploitation to society; since, this is the one that finally pays them, through prices of events and products, of these superfluous activities.

What is feminist movement doing to teach children and young people to work persistently? Instead of daydreaming.

BEAUTY CONTESTS, FILMS AND TELEVISION AWARDS: external physical beauty has become a new standard in society in the late 20th and early 21 st AD. in both men and women; becoming a stereotype that is very far from reality and ordinary people.

Those who by nature have been lucky and their physique is aesthetically attractive according to natural perception of beauty; however, it has changed or degenerated over time, they have taken advantage of it to obtain economic benefits without contributing positively to society in which they belong. This being another way of prostituting the physique of human being.

More importance, publicity and work have been given to improvement of aesthetics than to improvement of health (year 2021 AD.). 
What percentage of propaganda is directed at women and how much at men?

SOCIAL STATUS AND INDIVIDUALISM: Social status is a mental state of the individual through which it intends to make a distinction between human beings, believing itself superior to others, taking as tangible indicators the academic, economic level, external image, among others.

Development of individualism causes individuals to do whatever they want, no matter how much they harm their fellow men. On the basis that more they violate rules, more money they make, an aspect that is increasingly accepted by many. And what is worse, the respectful is called shy, lack of audacity, initiative and unfortunately lags behind.

\section{LIBERATION IN CLOTHING, SEXUAL, PORNOGRAPHY,} PROSTITUTION, OF WOMEN

LIBERATION OF WOMEN: By nature, human being wants and demands freedom, but when it is abused, consequences are unpredictable.

Relegation and oppression of women for many centuries, has led them to demonstrate against that oppression, the first women were silenced; from 20th century AD. that feminism has been expressed, liberation and empowerment of women, which at the beginning was and is legitimate, it seems that today $2021 \mathrm{AD}$. their behavior is pendular, from legitimate and moderate movement to debauchery and emboldening, indicators are many, only enough, wanting to see them.

There are hundreds or thousands of articles where women write on the subject, unfortunately many are biased, praise women and discriminate against men, others make statements that show and question the difficult behavior of women; of course, bad behavior of men should not be excluded. Positivist, negativist, and even biased articles could help define natural norms that should govern us.

Women revealed themselves to achieve them freedom and it seems they turned into debauchery.

Definition of debauchery: "like debauchery in doings or in words. By extension, debauchery is associated with moral violations and disrespect for religion". [Royal Spanish Academy (RAE), https://mx.search.yahoo.com/ search; _ylt $=$ AwrgEa7sSMFdbMEA 10DD8Qt.]

When there is a current of change that implies rebellion to established, e.g. "Hippies" (1960 AD.) Is normally accepted by young people and that subculture remains in that generation, its consequences appearing in adulthood and in education of children of that generation. Any current of negative change takes a generation to take hold; However, any positive current or correction of negative ones, take generations to see positive change reflected.

Feminism is a current of change, which is very important, it is desirable that its leaders seek a positive result.

Woman demands dignity; But she is a victim of vanity and commercial advertisements, especially all kinds of articles that improve her external aesthetic appearance and perhaps forgetting about her physical and mental health. Vanity does not generate satisfaction; it only exacerbates selfishness and individualism.

She is photographed half-naked on social networks, in vast majority of all kinds of shows, she wears elastic clothing that reflects the figure as she is, skirts and pants that are too short, it is the main focus on voluntary pornography. Adducing that she has the right to dress as she wants and man should not feel incited, provoked, seduced or excited, if he does it is because he is morbid, perverse and does not have to harass them.

For the sake of art, they have generated pornography for fame and money, for only showing themselves half-naked or naked, since the beginnings of cinema by some of the big stars.

Against who they compete with their painstaking grooming when they make up their face, dyes hair, gets cosmetic surgeries, or is a victim of age? Even risking their health.

Stop using crying and feelings of self-denial as a defense or manipulation mechanism, not doing so makes her more self-controlled. The fact that a mother loves, pleases and pampers her children and her husband is not necessarily a sign of self-denial if she imposes discipline and respect among all members and enforces them. Discipline and respect are given out of conviction and authority but not out of self-denial. There is no compelling reason why a woman should be self-sacrificing.

It is common to confuse love towards children, with cuddling them, spoil them and doing for them tasks they should do around the house, creating a lazy and irresponsible person. Woman will be liberated when she teaches children and husband that her mother and wife is not their servant.

Said by women: "Not all the love or all the money to women." "If your husband comes and tells you, get on the horse, don't ask, just do it." [said by a woman who was born in 1916-2012 AD. she at the same time learned it from her mother]

"We women have been stubborn since we were little." "Some only know how to demand and demand and their dreams of greatness want to obtain them through their husband." "There is no loyalty from woman to woman, one indicator is that we are always criticizing ourselves." [anonymous, by women]

"The secret to maintaining a good relationship is not to screw up so much, because women are heavy, even after we are dead, we screw up, or haven't you realized that most ghosts are women?" [WhatsApp video]

To what extent do these attitudes, which seem trivial, interfere in marriage relationship, in education of children and in the relationship between children? 
To housewife, few maids satisfy her and in general they do not like how man does housework, perhaps that inhibits his participation; although, it does not exempt him from his obligations.

"Contrary to popular opinion. The most important characteristic of a devoted mother is not her relationship with her children. It is her love for her husband, love between husband and wife is really key to progress of family". [John MacArthur]

Liberation of women is not equal to men and compete against them in all fields; each one by nature has his activities to carry out accompanied by necessary qualities to do so.

Woman will free herself, when she stops believing that she is "worth it", of being a victim of the economic system that praises and idealizes her and that she can be self-sufficient to live without a man by her side, or when she stops being an object in music videos, by nature we are codependent. When stop being a victim of beauty pageants where she is prostituting her body for the sake of fame and fortune. When stops being a trophy of man with money. Aesthetically attractive woman allows herself to be deceived or self-deceived, becoming at the end a victim, accusing man of being macho.

When she manages to understand and educate her boys without feeling of machismo and make the man understand that her greatest physical strength is not a factor of superiority; It should not be forgotten that education is breastfeeding and that women have a great influence on this task. It is perhaps here where women must truly protest loudly and achieve this goal.

How many women intelligently use their initiative and their feminine qualities to maintain a healthy and lasting relationship?

How many uses them to manipulate?

Saying: "I do whatever I want" or "men did not choose me; I chose my men." [Maria Felix, Mexican actress]

Liberation of women is not doing what she wants; As some women proclaim in the media, it is not being rebellious, debauched, or disrespectful.

"Is the fact that some women work for financial remuneration is a real necessity or just a fad of late twentieth century AD?" [Comment, MLChR, 2002 AD.].

REMARKS: Unfortunately, in some countries financial manipulations have impoverished people and it is necessary for many women to work outside home.

Perhaps liberation of women is in breaking the misunderstandings created at the beginning of 20th century AD., of raising children and housewife. Based on her home, take time off for herself; go out, seek out and participate in events that enrich herself, her family, society, that enhance her culture and her spirit and not her vanity. If required, do a remunerative activity.

Remove the stigma of talkative, gossip, scheming and assiduous viewer of soap operas so popular in recent decades, pretending to live through imitation of such events.

Some men, perversely have taken liberation of women at their convenience, taken advantage of debauchery, when some women may not know what they want to free themselves from.

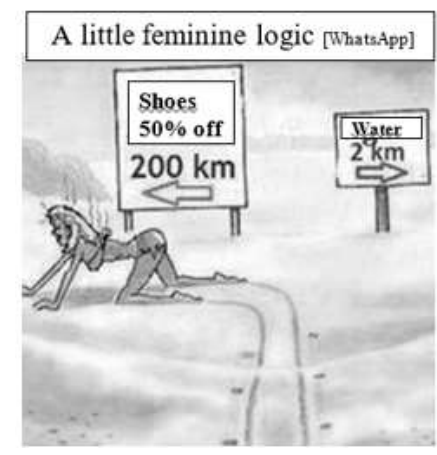

"Modern" woman (2015 AD.) Is still trapped in vagaries of "love" since, if a man flatters her, talks to her nicely, gives her especially jewelry and based on this he gets from woman what he wants, sometimes reaching manipulation, then mistakenly this man is considered a gentleman, tender and loving. In many cases they look down on the one who is a careful dedicated homebody who goes about daily chores because they are considered trifles. These women are the ones who think they are most liberated.

Anthropoecology implies having equality in some rights, equity and parity in others; but not equality in all aspects. Nature made us different and each of us has a well-defined role. Which, it seems that we have not wanted to understand.

Undoubtedly there are truly liberated women and sometimes man is too small for them in all aspects, frustrating her existence, being the one who performs all tasks, including livelihood. 
Is woman (2021 AD) fighting in the trench that corresponds to her or is she neglecting how fundamental children are at home?

Liberation is an attitude; debauchery is an activity.

LIBERATION IN DRESS: Pornography, prostitution and harassment start with the way women dress. Each human group has its own way of dressing, according to its climatic, religious, and other circumstances particular to its region.

Currently (2021 AD.) Women's way of dressing, in some social groups; Because of her sensuality, provokes men.

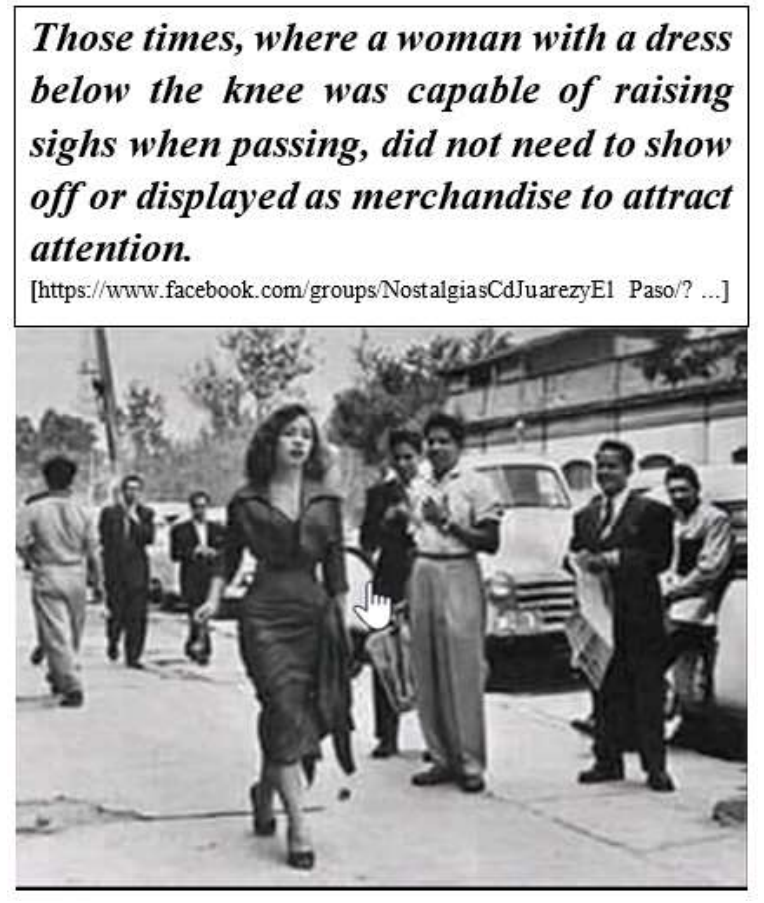

What is woman looking for with this manifestation of "liberation"?

Orthodox Jewish woman, she says: "Natural hair of women is attractive to men, so they cover their hair or wear a wig that is not attractive. For instance; on the beach, men are not covered, women are, because men are believed to have a natural weakness for women; Conversely, man needs more than woman to take care of his instincts, woman can control herself more and not get carried away by impulses. But for man it is more difficult. That is why women are more cared for in that sense, they are less seen so, as not to incitate men to look at her..." [https://www.youtube.com/watch?v=0cpjIzrBLwc, minute 24, video: Being a Jewish woman Orthodox, Guily Wiluzanski]

REMARK: that is a great truth. And by our whims we do not obey rules of nature.

"Fashion, the dress, garment that speaks for women. History of feminine dress is, neither more nor less, than the history of evolution of woman. How she put aside her position as a 'trophy' or 'companion' of man to become someone with rights, ideas and her own work, that is, an equal."

"When man began to settle down and invented agriculture and cloth clothing, although he did not substitute fur in the same way. Some women resisted putting on these new fabrics, due to their roughness that hurt their skin, but it was enough for men to praise their elegance and good taste for them to understand the excellence of that fashion and the need to sacrifice to be well dressed". 


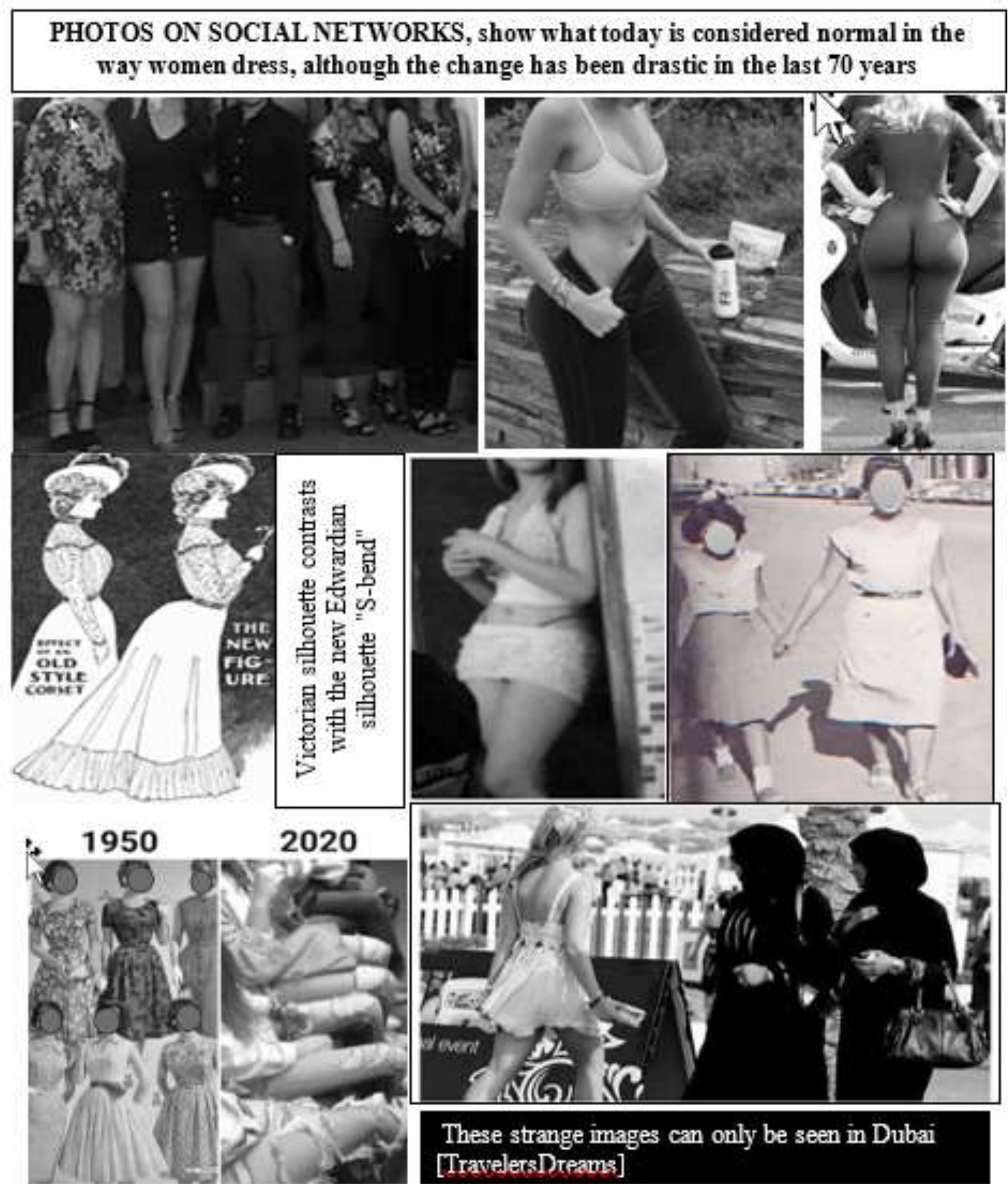

"In Renaissance, women began to be more aware of what their curves caused in men and they began to use it to their advantage, inventing a remote idea of cleavage. The dress is also a symbol of women's struggle to be recognized in "a world dominated by men"". [https://historiasdemoda.com/el-vestido-la-prenda-que-habla-por-las-mujeres/, 201602-26 Agustina Andujar Cavallo Destacados, Historias de Moda 0].

REMARKS: Is this honest, vanity, double standards, manipulation?

What is the meaning of such incitement and provocation?

What are women looking for when exhibiting themselves in this way?

Why are women used and on many occasions with little clothing to promote any type of product?

A serious debauchery of women, (2021 AD.) It is semi-dressing on a daily basis, showing sensual parts of her with small or tiny garments or tight to the body, calling attention of man, inciting and provoking. When a man is frustrated, he runs the risk of generating a sexual rapist. 
It would seem very easy to refute this argument with the fact that in some parts of the world, there are tribes where women do not cover their breasts, or some children walk naked; however, over the centuries they have adapted to this condition. African tribe video [https ://www.youtube.com/watch?v=ApOeuIok-HI\&list=PL5pYkOgkYg_8uFuOOWCg $X J X 7 s q E m v X D A U]$

Or is it that they are morally more advanced than those who believe they are and both their physiological and sexual needs see them naturally, without morbid, without malice, without prostitution and neither sexual exploitation?

Thousands of photos can be found, showing debauchery and far from legitimate feminism, liberation and empowerment.

A true liberation will give the woman a true empowerment.

SEXUAL LIBERATION: it does not imply debauchery, especially in the stage of puberty and youth of human being.

Making an analogy with sex; to14-year-old adolescents is not lend the car due to the risks that it implies due to their immaturity to carry out this task.

Is the same care taken with her positive formative education regarding sex and the responsibilities that this entails?

Are religions up to the task when it comes to sex education?

Human being by nature is a sexual entity, since childhood curiosity is generated about sexual organs and the pleasure that is felt when stimulating them; masturbation is a taboo subject, which will only be solved by educating children and adults.

Religious and secular opinions are as varied as they are opposed; But, to what extent are these opinions attached to natural rules of human sex?

Disorderly sex in recent decades (2020 AD.) Has led to disorderly procreation, with single mothers and irresponsible fathers.

It is very common to hear, "So and so is a womanizer" and to be such a thing, it takes more than one woman. Under natural instincts, woman-to-woman loyalty will be difficult, as every living being seeks its natural satisfaction.

The word love has been confused with sex; free love does not exist, what can exist is free sex. Sex was dictated by nature.

Love is conditional on reciprocity, be it a couple or any pair of individuals; or between mother and son, it does not imply sex. In love there is no debauchery. Love is cultivated, earned, given and maintained with daily positive attitudes and work, it requires feedback. In a relationship, love is given with what you have, if the recipient is not satisfied, it could be that expectations are different or that the customs where they grew up are different, in both cases, the relationship will be difficult.

PORNOGRAPHY: when sex goes outside its natural limits and enters the field of pornography, consequences are unpredictable since a very sensitive field of human being is being exploited. This seems to be a low-cost business with great profits.

Marketing has found a way to use the body, especially of women, to advertise its products with semi-naked bodies in any shop window and in full view of all. This is a form of pornography and prostitution. As well as the way of dressing (2021 AD.) Of "common" woman, the men and women "influencers" who are exhibited in tiny bikinis and sensual poses, which give the impression of being naked, painting their bodies as if it were garments to dress and go out.

"Pornography is the production and distribution of images about sexual acts, or sexually explicit content whose purpose is to provoke sexual arousal. It is about pornography distributed by companies whose sole objective is profit, which have taken advantage of fourth generation technologies $(4 G)$ and which position their offerings around the world. Degrading women, with increasing violence and sexist models

(Group sex with subjugated women, risky practices, violence)."

"It is practically inevitable that children and adolescents are exposed to pornography on Internet: porn is everywhere. In Spain, 86.9\% of young men are regular consumers, while young women only reach 54.6\% (Ballester, Orte and Red

Jóvenes e Inclusión, 2019 AD.), Finally, some conclusions are drawn that may serve guidance for professional intervention, as well as for the debate and definition of action strategies." [Pornography and affective-sexual education, Teresa Facal Fondo, Carlos Rosón Varela, Lluís Ballester Brage, https://octaedro.com/libro] 
PHOTOS ON SOCIAL NETWORKS: although they seem pomographic, "they are not" also appear in magazines and in the media at all times, where feminine aesthetics are praised. If the man is excited, it will be because he is a "degenerate" and not because of his natural reaction to the given stimulus. It seems that for women this is liberation and not debauchery.

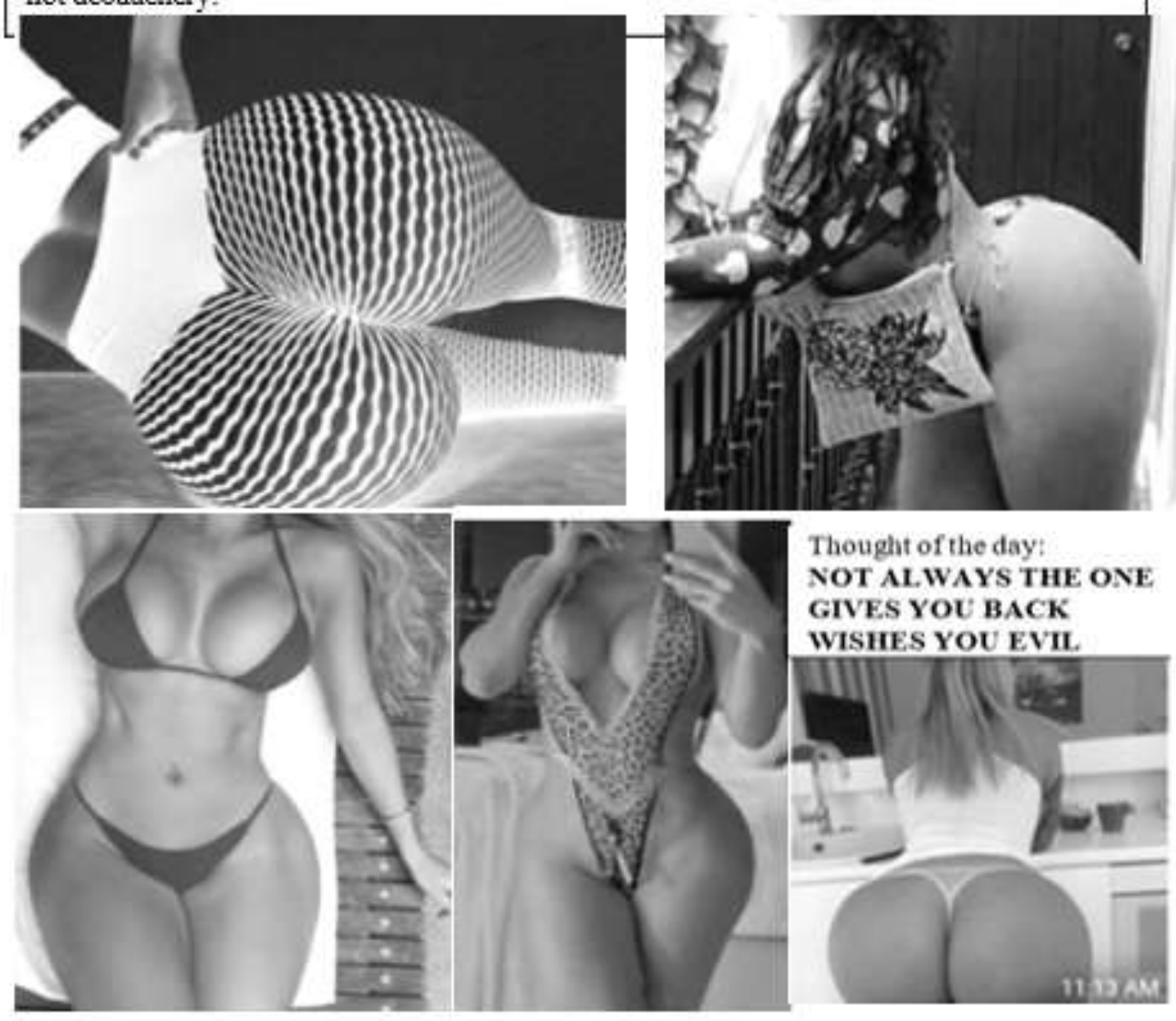


PHOTOS ON SOCIAL NETWORKS: although they seem pomographic, "they are not" also appear in magazines and in the media at all times, where feminine aesthetics are praised. If the man is excited, it will be because he is a "degenerate" and not because of his natural reaction to the given stimulus. It seems that for women this is liberation and not debauchery.

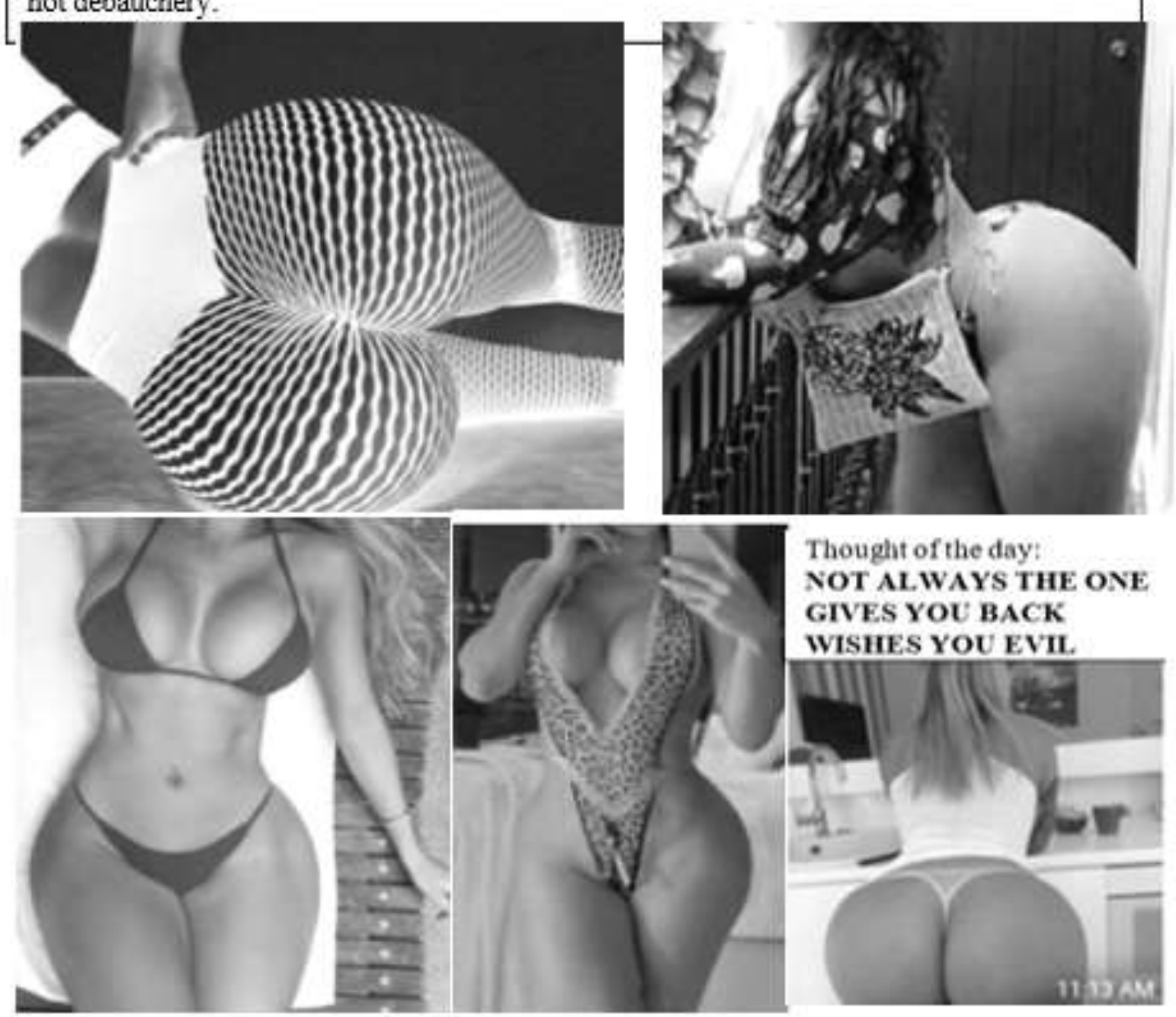




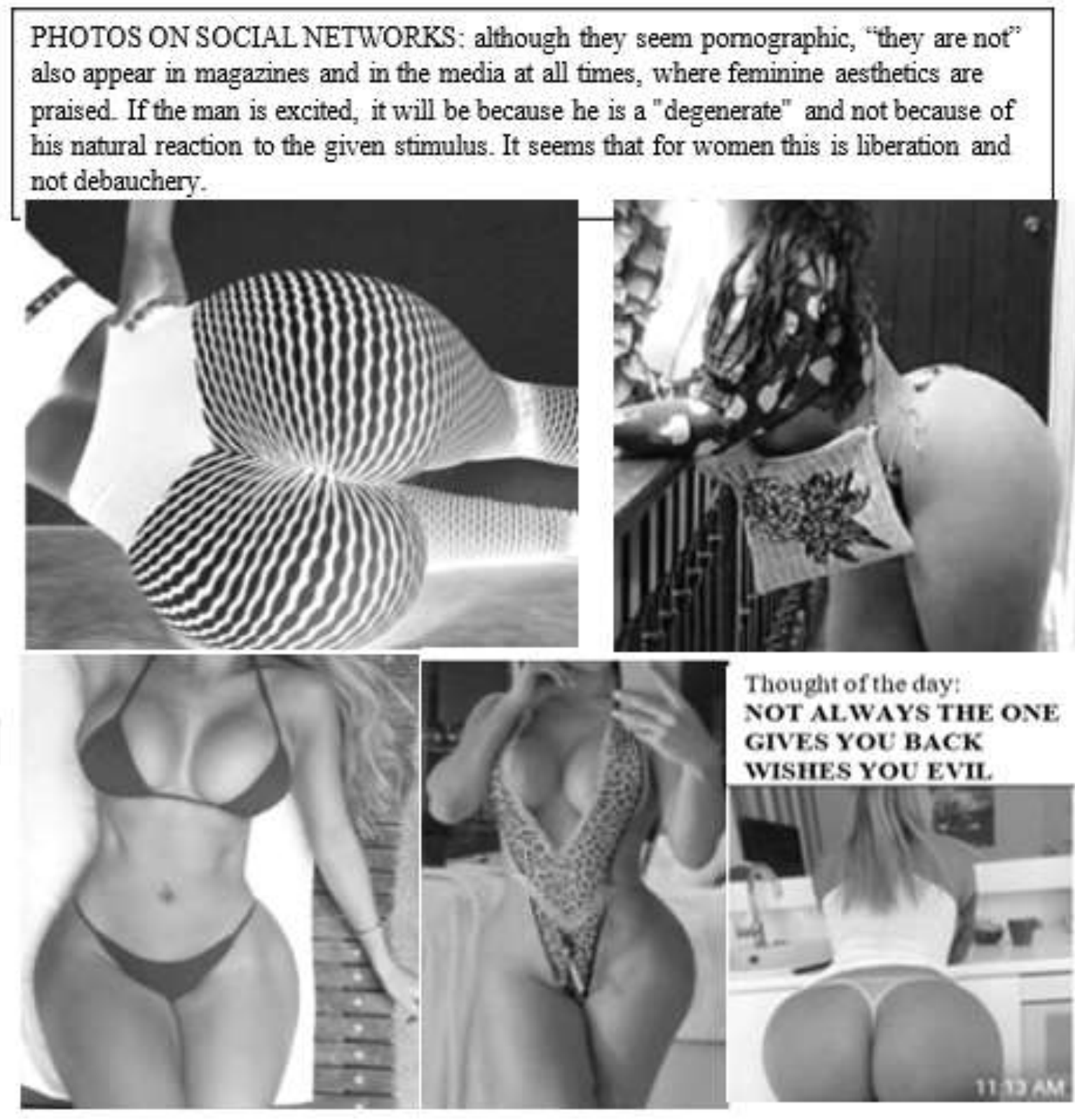

PROSTITUTION: it is known as one of oldest trades of human being and due to taboos, it is done surreptitiously so its exploitation is facilitated. One thing is the sexual act dictated by nature and another is the exhibition and exploitation of it.

What is the real reason for prostitution of women? For money? For sexual satisfaction? By exploitation? Who exploits whom? Who manipulates whom? Undoubtedly many women are financially manipulated; however, the sexual act itself is not a sacrifice when the man behaves appropriately.

True liberation of women will occur when she prevents being manipulated in pornography, prostitution of their sex and body. It is here where women must free themselves and maintain their dignity. True feminism has a lot to do in this regard.

In shows, cinema and television, women lose their dignity, her morals for the sake of popularity, fame and money, years later in some cases, they complain that they were abused.

"Is woman who uses her body on social networks free or does she respond to the market? Cristina Pedroche affirmed that she had never felt as free as when she came out half-naked to ring the bells, is that right?" [Mamen Hidalgo, MADRID, 05/29/2018 https://www.elperiodico.com/es/sociedad/20180529/mujer-cuerpo-desnudo-redessociales-6844963]

\section{FEMINISM}

"What is Feminism? it is a social movement that demands equal rights for women and men. Feminism, currently, is constituted as a current of thought that brings together a set of movements and ideologies, both political, cultural and 
economic, with the fundamental objective of achieving gender equality and transformation of power relations between men and women". [https://www.significados.com /feminismo/]

"Types of feminisms: Feminist movement is currently very diversified and highly complex. Feminism has been associated with communism and socialism, and some with anti-capitalism, it has been diversifying, meaning much more than emancipation of women. It is also associated with environmentalism or anti-racism. it questions that sexual freedom, rape, abortion, violence etc. should be put on the table"

"Types of feminisms: radical feminism, abolitionist feminism, transfeminism, equality feminism, difference feminism, socialist feminism, ecofeminism, cyberfeminism, philosophical feminism, separatist feminism, dissident feminism, liberal feminism, factual feminism or scientific feminism". [Types of feminism, https://www.muyinteresante.es/cultura/ photos / types-of-feminism / 1]

REMARKS: with so much diversification and currents of feminism, it is difficult to concatenate ideas, purposes and desires, being able to lose the original objective, and being manipulated.

Feminist movement of any kind, in order to achieve its objectives, it must clearly focus its requests to high-level institutions, whether they are organizations, administrative policies, religious, etc. and stop focusing as an attack on men in general, because this; perhaps, it originates pseudo-feminists who do not understand true feminism. It is not the common man who controls ideologies.

“FEMALE AUTHORITY AND GENEALOGY: have to establish a genealogical relationship with their own gender, a relationship that requires the existence of figures that allow giving a body and a name to female subjectivity. In this way, a feminine culture can begin to take shape, which allows women to build a model of identity inserted within their gender". [http://www.cdp.udl.cat / coeducacio / index. php / en / authority-and-feminine-genealogy].

"FEAR OF WOMEN (GINEPHOBIA): CAUSES, SYMPTOMS AND TREATMENT: those affected, mainly men, feel an irrational phobia in the presence of women. Gynephobia clearly speaks of a pathology."

[https://psicologiaymente.com/ clinic/fear-of-women-gynephobia]

"Why are men afraid of smart women? Thus, it was seen when feelings that unite both people are activated, female intelligence stops causing fear because man thinks of their relationship as a team game». Of course, this does not mean that all men are intimidated by female intelligence. When asked who they preferred as a couple, men did not hesitate: the smartest woman. However, there is a small problem, that she is not smarter than me". [https://www.lavidalucida.com/por-que-los-hombres-have-miedo-de-las-mujeres-inteligentes. html, Dayerlin Sosa López] 


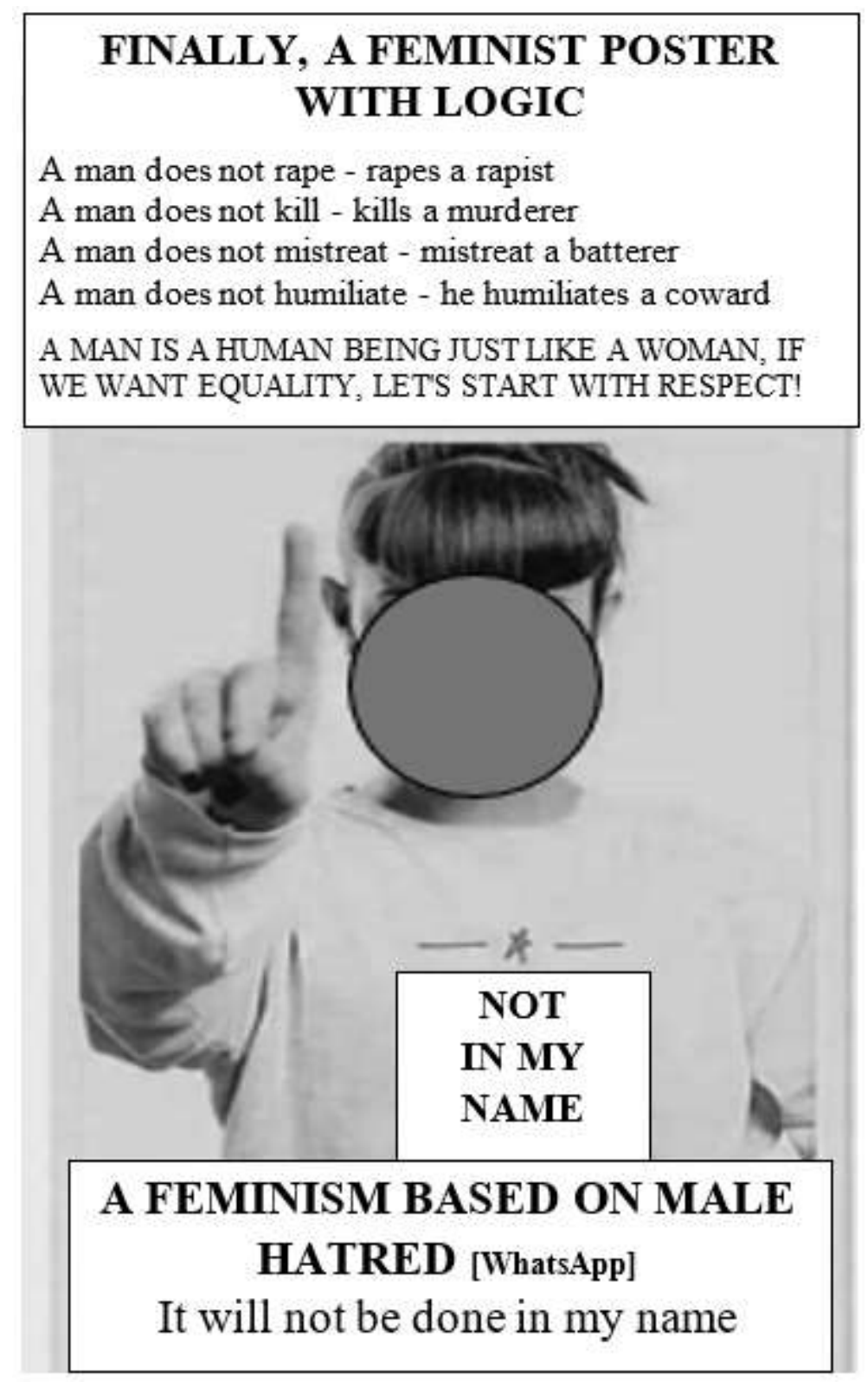

"ARE MEN AFRAID OF STRONG WOMEN? WHAT'S UP ... after all, men are not afraid of anything or anyone. However, the thing is that men feel self-conscious about some women. You are a really wonderful woman, but the truth is that you scare me a little."

"Are you a woman who is down to earth? A woman who works tirelessly and doesn't allow herself to be "dominated" so quickly? Congratulations! You are exactly the type of woman most men desire! But, as a woman who keeps her life under control, you probably tend to demonstrate this strong personality, this "fighting nature" externally as well. The problem is that men consider a woman who appears strong and fighter, as COMPETITION. We interpret this behavior as MALE and not as female". [http://www.entender-al-hombre.net/index.php/ entender-a-los-hombrescomo-piensan-y-sienten/los-hombres-tienen-miedo-de-mujeres-fuertes, Christian Sander]

REMARKS: perhaps that woman with a "fighting nature" has objectives that are incompatible with tasks of forming a couple, having and caring for children. If the sense of competence at work is viewed pejoratively, for a man a woman is the same as another man. "Of course, this does not mean that all men are intimidated by female intelligence". If we start from the basis of gender and not of the individual; if there is fear, this is between individuals, a man, the same, can fear a woman than another man. Man is not afraid of true smart and strong woman. What can happen is that some men do not feel capable of matching some women in their qualities and they are respected, not afraid; however, most men fear an emboldened (bossy) woman who thinks she is smart and strong. It seems that gender is being confused with behavior and disrespect, where some women try to show that they "can". Man, in general, does not think that the 
relationship is a competition. It seems that the article considers all macho men and it is in any case the sexist who has no respect for women.

“MEN'S FEAR OF WOMEN. Examine all laws relating to women with which your ancestors subjected their freedoms and by which they subjected them to their husbands. And even though you are limited by all these restrictions, you can barely master them. What would happen if you allowed them to break those laws one by one, dislocate them and, in short, make them equal to their husbands? Do you think you could bear them? As soon as they begin to be equal, they will be superior". [Titus Livio (59 BC - 17 AD), Roman historian].

"There is a fact that is true for me: that we are not educated in the knowledge of what we are unequal; on contrary, we are educated as if a man and a woman were the same by nature". [The Myth of Women, Genaro Chic Garcia, https://www.academia. edu/37102787]

REMARKS: "Do you think you could bear them?" For 20 centuries, this phrase shows how difficult it can be to live with a woman and it seems that for so long we have not paid attention to it, neither men nor women. "As soon as they begin to be equal, they will be superior." Of course, there are some women superior to some men, but by nature we are not equal.

GENDER PARITY: a matter of equality and justice. Gender parity refers to balanced participation and representation of women and men in positions of power and decision-making in all spheres of life. [https://www.gob.mx/inmujeres/articulos/la-paridad-de-genero-un-asunto-de-igualdad-y-de-justicia? idiom = is]

\section{EQUITY, EQUALITY AND PARITY}

EQUITY: "means that each one receives what is due to him or what he deserves". [Mónica Mancero Acosta, EDITORIALISTS, JANUARY 2014]

EQUALITY: "instead, it implies receiving the same treatment without considering the differences". [Mónica Mancero Acosta, EDITORIALISTS, JANUARY 2014]

PARITY: "even", which can be translated as "equal", and the suffix "-dad", which is equivalent to "quality". [https://definicion.de/paridad/]

REMARKS: if equality is sought in all spheres of life, we are assuming that we are equal by nature, it would only lack to wish that woman beget and children will be given birth by man.

“THE PERCEPTION OF A FRENCH YOUTUBER THAT SHOULD SHAME MEXICO. A French YouTuber has shaken the hornet's nest with advice that no one asked for. Among "10 things you should not do in Mexico", young woman advises women "not to wear flashy clothes because it attracts eyes a lot." No skirts, dresses or short shorts because, literally, you would be the focus of attention wherever you go. Josephine Wit, is the name of this girl who a year ago was on a school exchange in Guadalajara and now has decided to reside in Mexico."

"Teresa: Since when does being whistled or given a decent compliment is harassment? Already touches and obscene words yes, but a simple hiss and a good compliment No ... do not exaggerate things please!"

"Mario: Because the look of a man towards an almost NAKED woman is interpreted as sexual harassment and the fact that a woman is almost NAKED isn't, isn't this FEMINISM as bad as MACHISM? or even discriminatory? A halfnaked woman should not be considered a stalker?"

"Andres: Women say not to whistle at them because they are not dogs, then men should answer that they do not show us their flesh (or hides) because we are not dogs either. That they do not provoke us with their way of being or dressing, that is the key." [Katia Monteagudo, Yahoo News November 4, 2019]

REMARKS: "advises women not to wear flashy clothing because it attracts eyes". She is saying it herself and reactions to the article are explicit enough. This perception can happen in any society.

\section{FEMALE EMPOWERMENT, 5 REASONS TO \\ START FROM CHILDHOOD}

1. "Because they will learn to be brave, not perfect. Most girls are taught to avoid failure and risk to focus on safe play, to be perfect in everything they do. Children are encouraged to be brave. Why do we teach girls to be perfect and boys to be brave?"

2. "Because gender stereotypes are acquired from childhood. Girls start to feel less intelligent than boys from the age of $6 . "$

3. "Because it contributes to preventing violence and discrimination. In addition to fostering leadership and selfesteem in girls, it is also necessary to educate boys and girls in gender equality from an early age. At very young ages (0-12 years) prejudices hardly exist."

4. "Because today's girls will be tomorrow's leaders. As the UN recalls, investing in your potential defends your rights now and promises a more equitable and prosperous future."

5. "Because development without them is not possible. Only with men and women living together in equality will it be possible". [https://ayudaenaccion.org/ong/ blog/mujer/empoderamiento-feminino-infantil/, Begoña Rodríguez Pecino]

REMARKS: Women by nature seek security and risk less. What is the feminist movement doing to educate girls and boys about mutual respect? Is there a committee that deals with these kinds of issues? 
By nature, woman is more meticulous and careful to do her tasks and man with courage or fear, has to go out to find sources of sustenance for his tribe. This still happens in some tribes of Africa (XXI AD.). Proof that we should not educate equal in all aspects, but educate to understand each other. [https://www.youtube.com/watch? $v=b \_u R-V U o$ Cos,]

Gender stereotypes are not acquired from childhood, they are by nature, a positive formative education is required to understand them and not compare intelligences, prevent violence and discrimination in both ways and that each person develops according to its own abilities and not with conditioning laws to achieve equality. Only with equity will a healthy coexistence be achieved, regardless of personal or global development. We scandalized when the issue of sexual education for children and adolescents in schools is discussed, but we lose our shame when an adolescent is taken for an abortion clinic. We are one of the species where male is easily distinguished from female; but, the only one who wants to equalize.

In politics. Where are the results and public policies of political feminists in favor of society, which proclaim to protect and give well-being to citizens?

\section{ABORTION AND FEMINICIDE}

"ABORTION: according to the World Health Organization, it is the interruption of pregnancy before fetal viability with adequate means. This definition makes no mention of whether the fetus is alive or dead. While from a legal point of view abortion is considered the death of the fetus". [WHO. Abortion. Report of a scientific group. Technical Report Series No. 623, Geneva, 1978.]

"An abortion is the termination of a pregnancy. It is the death and expulsion of the fetus before five months of pregnancy". [https://www.google.com / search? definition + of + abortion + oms \& oq $=$ definition + of + abortion \& gs]

REMARKS: "The WHO says; It is the death and expulsion of the fetus before five months of pregnancy". You can only kill a living being, therefore, an abortion is a crime, according to the WHO. killed.

If you kill a worm or a chrysalis, you cannot be accused of killing a butterfly; but yes, that a living being is

Abortions are undoubtedly traumatic for those involved in it. Why not opt for prevention through positive formative education. What prevents us from doing so?

Abortions are undoubtedly traumatic for those involved in it. Why not opt for prevention through positive formative education. What prevents us from doing so?

"Why is it intended to decriminalize abortion? Human Rights Committee of United Nations (UN) manifested itself, for first time, with a strong position regarding voluntary interruption of pregnancy. It did so through "General remark $N$ ○ 36", which was drawn up at the end of 2018." [http://www.abortolegal.com. ar / the-un-issued-in-favor-of-voluntaryabortion /]

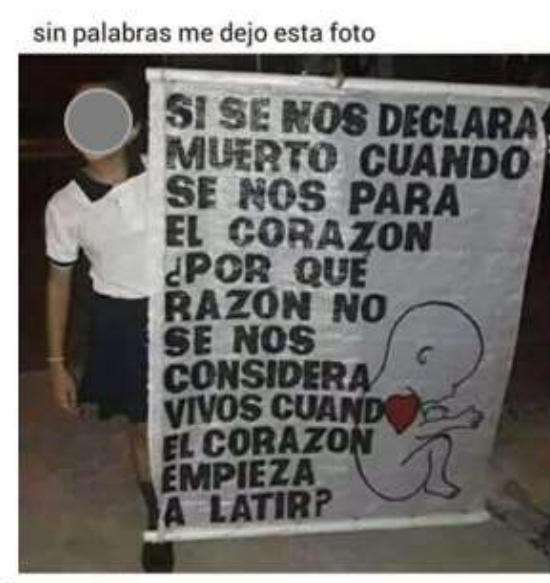

“Wordless by this photo."

"If we are declared dead when the heart stops. Why are we not considered alive when the heart begins to beat?"

\section{"The first heartbeat of the fetus"}

- "Fetal heart begins to form in the fifth week of pregnancy."

- "Heartbeat of the future baby can begin to be seen on ultrasound from sixth week of pregnancy, and can be heard between the eighth and tenth weeks of gestation with a device called Doppler that amplifies sounds. First time is usually quite impressive!"

- "Between 18th and 20th weeks the heart is already beating so loudly that it can be heard by placing a stethoscope on pregnant woman's belly. $A$ belly that at this stage of pregnancy will already be well visible."

[https://www.serpadres.es/embarazo/tubebe/video/los-primeros-latidos-del-corazon-del- 
REMARKS: If we talk about decriminalizing, it is inferred that it is a crime, or that the perception as a crime was wrong. If it is required to legislate it, would it remain as a "law", that it is no longer a crime? And if it is not a crime.

Why legislate it? So that it remains as a "right" that allows a crime?

It seams that the position of the World Health Organization and United Nations, are not the same.

By nature, by biology, by religion or ethics: When does a human life begin? Anthropologically, after the moment that human life begins, ABORTION IS A CRIME. As any stage, the worm, chrysalis or butterfly, a life is interrupted.

FEMINICIDE: "It is defined as the murder of a woman at the hands of a man for machismo or misogyny. The concept defines an act of maximum gravity, in a cultural and institutional context of discrimination and gender violence, 1 which is usually accompanied by a set of actions of extreme violence and dehumanizing content, such as torture, mutilation, burns, cruelty and sexual violence, against women and girls who are victims of this". [https://es.wikipedia.org/wiki/Feminicide]

"Femicide a persistent global plague. Thousands of women die every year in the world for the simple fact of being women. In 2017, the victims reached 90,000. It is a plague that affects rich and poor countries without distinction, those that are at war or at peace". [https://www.chicagotribune.com/hoy/ct-hoy-feminicide-plaga-mundial-persistent20191119-oaaswcwjzfbohf2llvza4dinle-story.html]

REMARKS: without a doubt the 90,000 murdered women can be classified as femicides. About the 42 million abortions in $2019 \mathrm{AD}$. How should the 21,000,000 million girls deprived of life by abortion be classified?

We are so wrong or alienated that abortion pretends to be a human right and not a crime, even when it is "legalized". Legalized to dismember a "non-human" being.

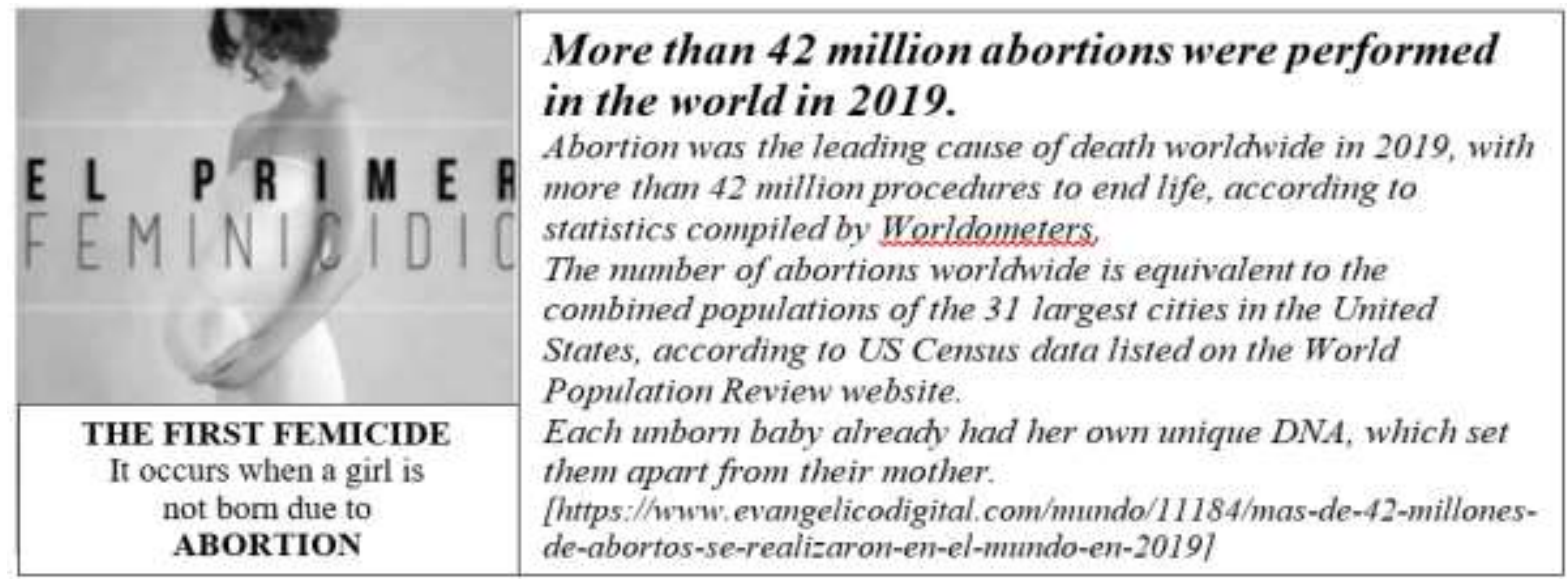

"You cannot say first that "THAT" is not "HUMAN "and then the minute SELL IT as human organs". IUSA senator. James Lankford]

It will be necessary to be careful which murders of women are true femicides and in which the woman was involved in dishonorable matters, of which there are several examples. Others, by their folly, consciously exceed the patience of an impatient; in which, with her "charms" and coquetry she consciously hurt the feelings of a male. None of them ceases to be a crime, the existence of intolerant males is not denied; therefore, we have to sit down at the table and analyze its entire context. Are these aspects, among others, taken into account in the investigations? Or only the feminicide is seen.

Without a doubt, any crime is detestable and unfortunately, they happen to both women and men, only that for some reason since the ideology of feminism was created, violence against women has been demonized, instead of focusing efforts on positive formative education. 


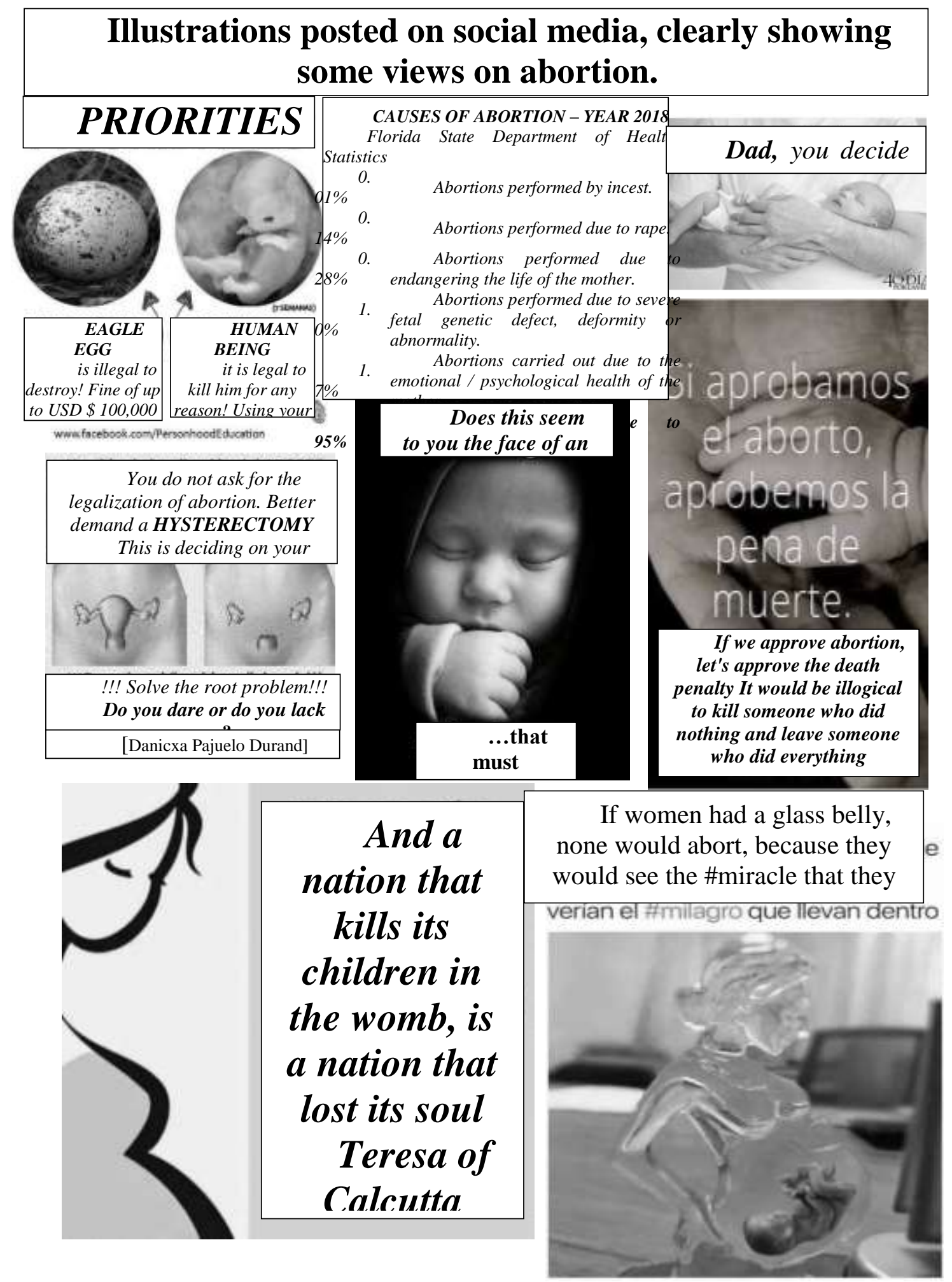

HARASSMENT, HEMBRISM, MACHISM, EDUCATION

"HARASSMENT: when a person harasses, persecutes or annoys another, they are incurring some type of harassment. The verb harass refers to an action or conduct that implies generating discomfort in the other." [https://mx. search.yahoo.com/search? fr =mcafee \&type $=E 210 M X 91215 G 0 \& p=$ definici\%C3\%B3 $n+$ de + harassment]

Duality: when an attractive man flatters a woman and she likes the man, then he is a gentleman; But when, the man does not like, then he is a stalker. Harassment is given the same, only that from woman to man it is called seduction.

Nudity of the man vs nudity of the woman. 
How far could a half-naked man show himself on the street or just walk around in tight clothes and show his genitalia?

At the very least he will be accused of stalking, making a scandal in the media, being taken to the police with all kinds of related charges; However, how far do semi-naked women show themselves, in "mini short", with necklines partially showing their breasts in public or with tight clothing, showing their sensual parts, which sometimes show their genitalia?

Do you call this liberation and empowerment, owners of its body?

Today "liberated and empowered" woman insults and offends the man and if he simply answers her, at least she accuses him of being macho, violent and if it is not enough, she accuses him of a rapist without further proof than his word and "laws", believe her. As has happened with the accusations of "harassment and rape", in some cases 30 years ago, the evidence of which remains in bickering, but it discredits a man.

If a man raises his voice before the woman's stubbornness, she accuses him of violence; some good and sensible women have lost their ground and fallen into a misunderstood feminism, liberation and empowerment.

Said by men: "among jokes, men say that in their house there is a cross-legged strike and that he is being punished." [Anonymous]

REMARK: this is a serious error because the need and lack of loyalty from woman to woman are factors that induce infidelity. Infidelity of both.

Said by men: "the woman wants you to guess what she wants as a gift and if he doesn't hit it, she at least gets upset". "When you ask her, what restaurant do you want to eat in? They answer 'where you want' and if you don't guess where she wanted, you spoiled the time". "Woman does not recognize offenses o mistakes that she makes, she simply denies them or she is silent". "The woman resorts a lot to the blackmail of crying to achieve her purposes and that is insane". "If a man comments on a romantic song, the woman extrapolates the comment and says, who do you remember?" "Does the woman have any idea how much a man changes his habits when he marries?" [Anonymous]

REMARK: Pragmatism of man requires concrete answers and not dualities, that can be seen in the short and concrete phone calls.

"Myth or truth Dissatisfied women: I would not say so much that we are not satisfied with what they give us, it is that our taste and need fluctuate a lot, as well as PMS and pregnant women, we have billions of needs. No, it is not easy to hit the first one definitively, but here patience is a virtue and they say that whoever wants blue sky that it costs, right? 
PHOTOS ON SOCIAL NETWORKS: these photos provoke the men; Supposedly in a few decades, we have "changed and advanced", but nature will not change us at will in the same way. For some it is a normal way of dressing and behaving. This may be because from girls they are used to wearing shorts and as adults, it will be very normal, misunderstood liberation.
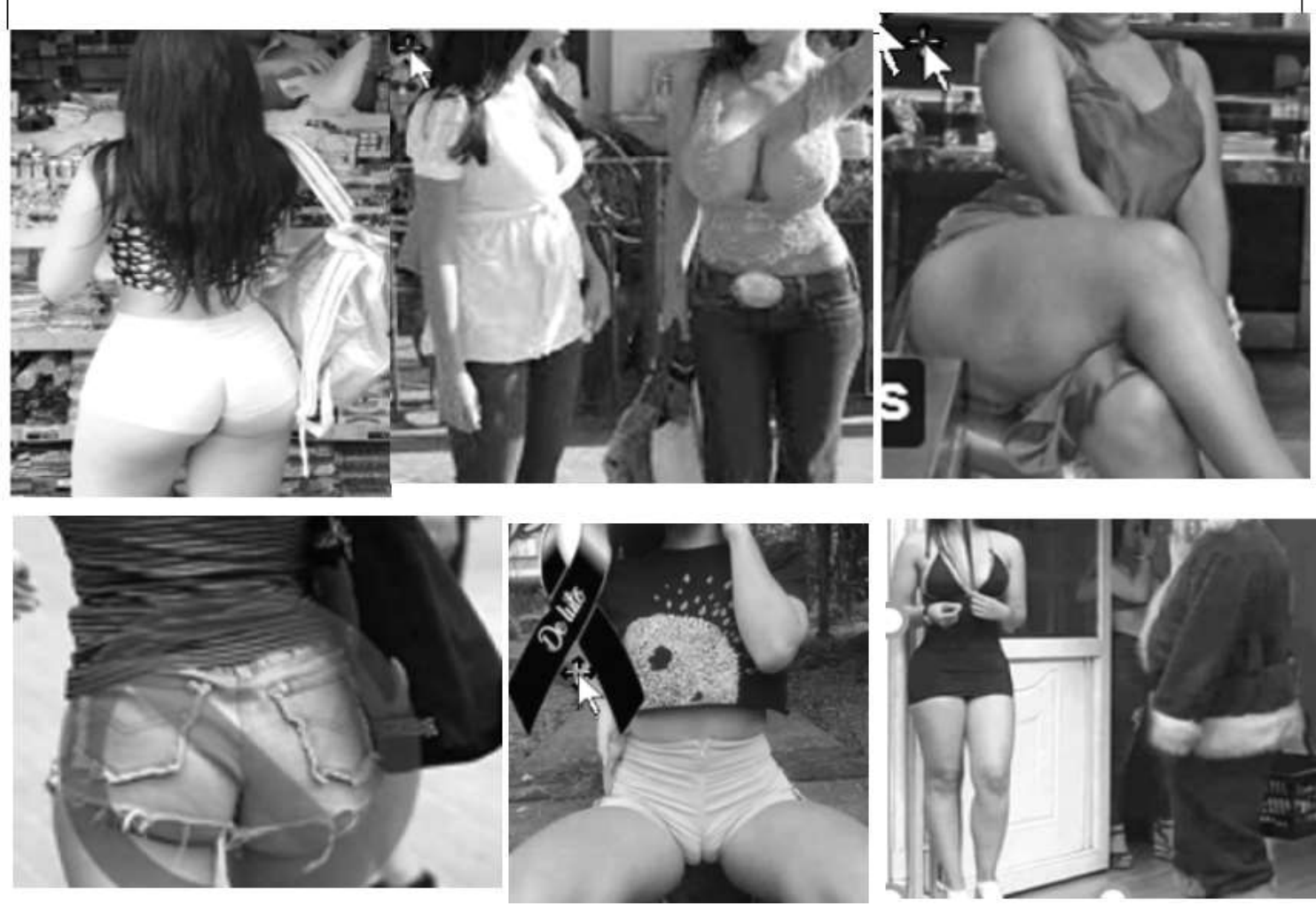

Ma. Luisa: We cannot get off the hormonal roller coaster to which we are subjected, but we can control our character. Sometimes I feel like a princess and sometimes I feel like a beggar; however, the latter I can make up with a smile. People are not to blame for my colic or my bad mood. Women can speak directly without detours, tell our partners what we want or what bothers us without having to put together a theater. There are many women who love to go off on a tangent. To be satisfied we have to speak clearly, otherwise we will always be dissatisfied and we will always make life miserable for the couple". [Tania, By El \& Ella | El Ella - Wed 23 Nov 2011]

REMARKS: "I would not say so much that we are not satisfied with what they give us." Vast majority of men contribute everything they can; if you are not satisfied, you got the wrong man. "We have billions of needs." "Whoever wants sky blue that costs him, right, isn't it?". This implies that this woman does not know what she wants, less will her couple know it or it is a perverse game to control him, causing indifference on the man. Self-flattery is self-centeredness, if you start from that base, you can say that you are talking about a libertine and emboldened woman and not liberated or empowered one. 


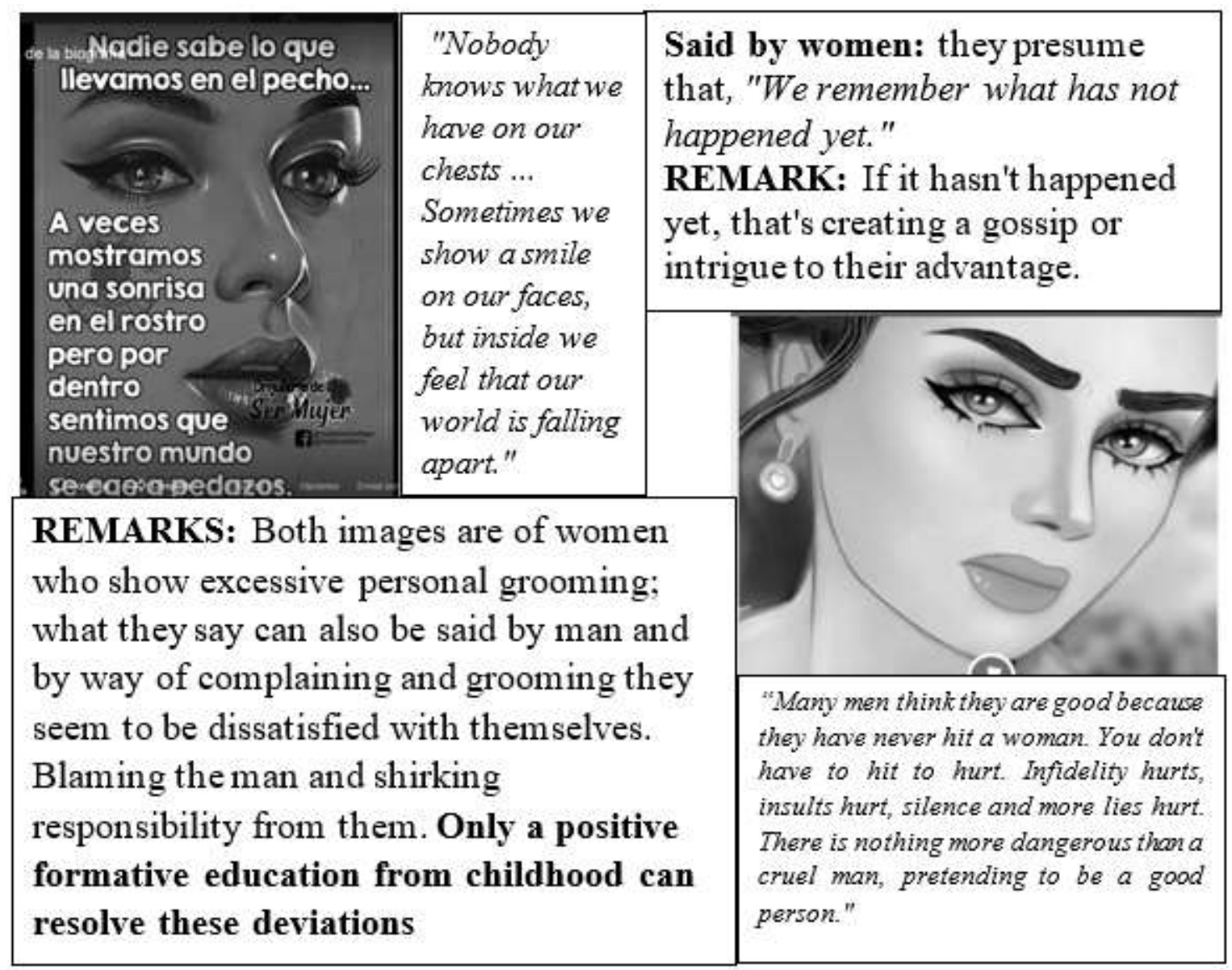

\section{HEMBRISM}

"What is Hembrism? The concept of hembrism can refer to a certain attitude of contempt towards men, sexual discrimination towards men, or the idea of superiority of women over men in all areas of life.

For some, feminism is what is known as misandry, an attitude of hatred, aversion or contempt towards the male and everything he represents. Which can lead to forms of violence or mistreatment against people of male gender. Hence, it is considered the opposite equivalent of machismo.

Radical feminism (also popularly called feminazi), are hembrism. Creation of the concept of feminism is a consequence of machista fears towards advances of feminism towards a more egalitarian society.

Hembrism and machismo are two positions that are totally opposed to gender equality. In this sense, they have in common being both radical positions regarding equal rights between men and women". [https://www.significados. com/hembrismo/]

REMARKS: hembrism is not new, it occurs in the privacy of home, since time immemorial, only that man hid it out of shame, the woman was identified as bossy and that still exists (2021 AD). The bossy man, woman calls him macho.

Woman with her brain ability (some women call it superiority) manipulate man and without realizing it they fall into stubbornness, they believe that man does not realize it, only that majority accept the event, thinking that after all things must be done.

Nature is not wrong, the physical weakness of women, compensates with brain ability to handle complex situations. As a humble opinion, the most complex is pregnancy and giving birth to a child.

With liberation turned into debauchery and empowerment into emboldened, hembrism has manifested itself openly; falling, like machismo in an extreme pendulum posture.

It is regrettable to say it; but woman accepts and promotes machismo. One manifestation is the music videos, where there is a male singing surrounded by women, dressed in bikinis and flattering the male. That is self-denigration.

POSSIBLE CASE OF HEMBRISM: "a man and a woman try to steal an ATM, a user confronts them, the one who responds and assaults the user, is the woman, within her arguments she tells the user, "HIT ME I'M PREGNANT". [WhatsApp] 

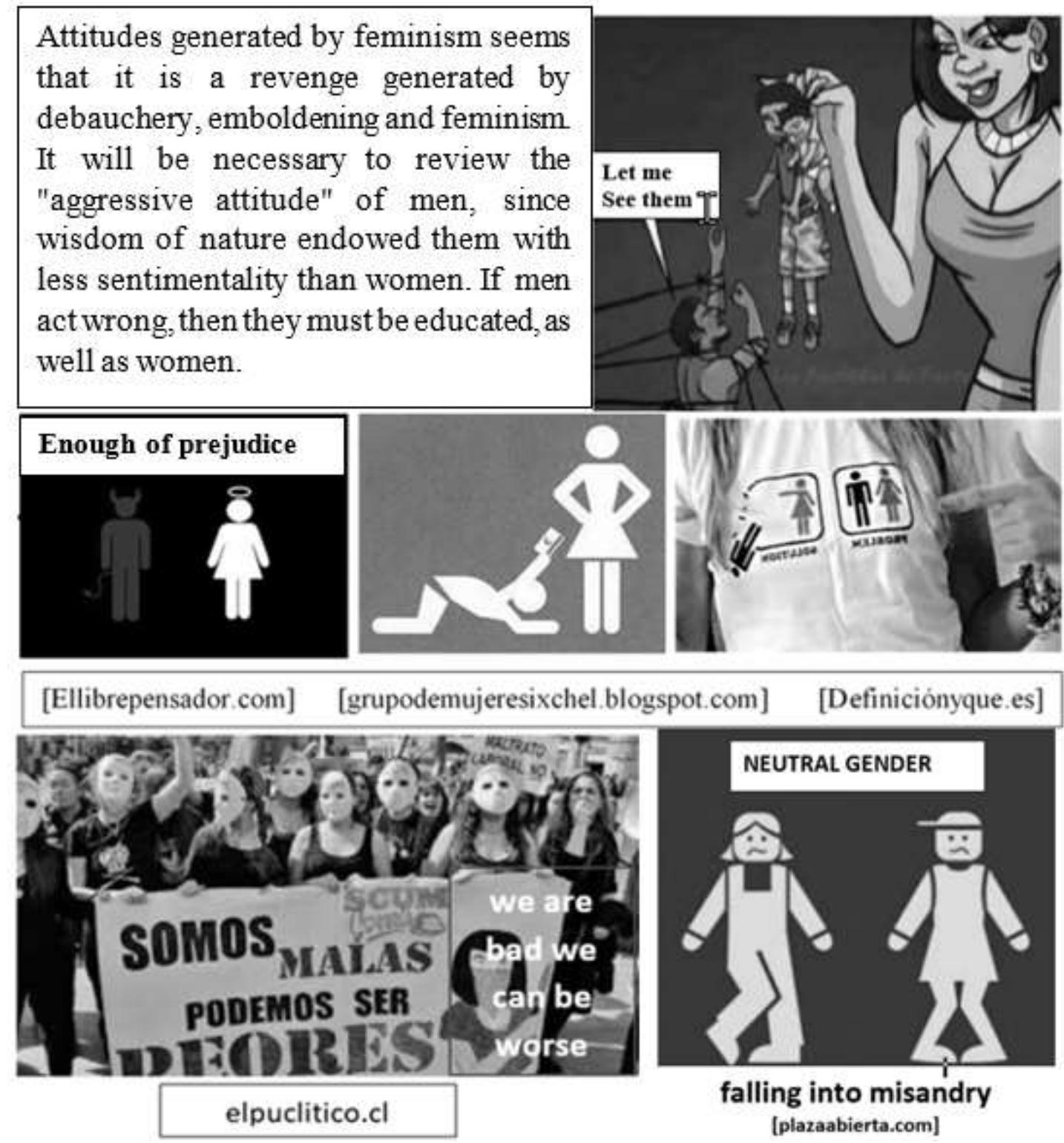

falling into misandry

[plazaabierta.com]

REMARKS: How to qualify this rudeness of this woman, impudence, shamelessness, arrogance, emboldening, hembrism? If it had been the man who responded and assaulted the user, the response would have been different. In this case the woman is manipulating her "weakness" to take advantage of the situation. In this case, the woman manipulates her "feminism" to act with debauchery and emboldening.

"Hembrism or call it what you want, within feminism there is a sector that denies the existence of hembrism and even calls it a macho invention. One of the arguments sometimes made is that hembrism is not a system, as is patriarchy.

Misogyny: Aversion or hatred of women.

Misandria: Aversion or hatred of men.

Machismo: Attitude of discrimination or undervaluation of women.

Hembrism: Attitude of discrimination or undervaluation of men.

Patriarchy: it is a social system dominated by men.

Matriarchy: Social organization, in which the command resides in women." [https://andressolo.wordpress.com/2015/12/01/hembrismo-o-llamale-como-quieras/]

Some feminists say: feminism is struggle, feminism is equality, feminism is vindication, feminism is "\#stop" to machismo. [larealidadescondida. wordpress.com]]

REMARK: Women denies the hembrism as men the machismo, both attitudes exist and as long as they are not recognized, we will continue to be trapped in these social problems. It seems that some feminists have misunderstood feminism; saying: "feminism is \#stop machismo."

Demonstrations of the Women's Day march in CDMX: "Enough is enough" 
Mexico.- "We want each other alive, free and without fear. Not one less. That femicide violence, which takes the lives of at least 10 women a day in the country, stops". "No violent man may enjoy impunity," was read this Sunday in another of the banners, displayed by Carmen, a woman who was the victim of an acid attack at the hands of her expartner. If one day I don't show up, don't light candles, let them light barricades". [https://www.animalpolitico.com/2020/03/mujeres-marcha-8m-cdmx-protesta-machistmo/]

REMARKS: As can be seen, are messages of aggressiveness. It is known that violence generates more violence, at any level. Only with positive formative education will the problem be solved. It seems that there are no long-term solutions.

“WHAT IS A KAREN? The new term that is used (2021 AD.) To identify a feminist or sexist and racist woman for a white woman is <Karen>”. [https://www.youtube.com/watch? $v=q 5$ Mh9Fl9px8].

"A Karen, is a middle-aged white woman, she is considered ignorant but too proud and self-centered to admit it, she usually complains about anything for no reason because apparently she has nothing better to do, she is characterized by her hairstyle, before any inconvenience, they ask to speak to a supervisor, they are racists and xenophobic, they complain that they don't pass the ball to their son in a soccer game, insult an employee, yell at the teachers because they failed their son." etc....

"Stop saying Karen": "Karen is a sexist and racist term equivalent to the " $n$ " word for white woman. Calling a woman Karen is an attempt to get rid of women's right to defend themselves". (Said by Karen themselves) [https://youtu.be/q5Mh 9Fl9px8?t=19]

"Karen, What the term means? Heather Suzanne Woods, a meme researcher and professor at Kansas State University, recently told The Atlantic that the defining essence of a Karen is the right, the selfishness and the desire to complain. These women demand that the world exist according to their standards, with little respect for others, and are willing to risk or degrade others to achieve their goals." [https://ismorbo.com/que-significa-el-termino-karen/]

REMARK: controversial opinion, the same "Karen" complain that the term is sexist and discriminatory, which affects their rights, when they are the ones who do not respect the rights of others.

\section{MACHISMO}

What is Machismo? it is a form of sexism in which women are discriminated against and belittled, considering them inferior to men. Machismo is founded on preconceptions and stereotypes, strongly influenced by the social environment.

Machismo has the idea that the mentality of women should have an attitude of submission towards men manifests itself in different ways, for example, with attitudes and behaviors of contempt and control. On some occasions, it manifests itself in physical and psychological aggressions and is known as gender violence.

In patriarchal societies, society is organized in such a way that man exercises his power over woman in different spheres (for example, in politics, economy or family).

However, in societies that are not considered patriarchal there is also machismo and the way it manifests itself speaks of covert machismo.

Machismo and feminism: feminism, in contrast to machismo, is a movement that vindicates the role of women in society and advocates equal rights between women and men.

In the world of education, be it formal education or family education, there is a deep-rooted tradition in many places where certain social roles are inculcated. There are also criticisms of the way language is used, for example, giving preference in some languages to the use of the masculine gender ('There were boys and girls. They were very funny.') [Https://www.significados.com/machismo / January 4, 2021].

REMARK: Undoubtedly both male and female behavior are harmful and should be discussed openly, restoring the natural roles of women and men, through a positive formative education from childhood. Feminism is an ideology, which if misused could be negative, machismo and hembrism are negative attitudes.

\section{EDUCATION}

It is very common for young people to compare the "freedom" of other societies with which they live, in some societies there is great debauchery in some cases promoted by the media, with violent and alienating virtual games of all kinds and the internet with harmful messages. Societies that have a positive formative education must compare societies and explain to young people the difference between respect, discipline and debauchery.

Natural sentimentality of woman limits her disciplining her children, pragmatism of man is perhaps more objective about the good or bad behavior of children. For existence of human being, both factors are necessary, excess in both is harmful. This expression is very common: "when your dad arrives, you'll see".

Objectivity vs Subjectivity; It seems like a joke, but it is very frequent; e.g. Event, roast beef (Mexico), Description: "group 1, 15 men; group 2, 15 women. Group 1 in 18 information exchanges decided to do it. Group 2 with 169 exchanges returned to the initial question." [WhatsApp]

REMARKS: women do not standardize criteria on roast beef, they mix other daily aspects, each one wants their own thing. This shows us that we are different and we must educate ourselves to understand those differences. Both attitudes are necessary and complementary. Nature does not make mistakes. 
OTHER EXAMPLES: "DEAR MOTHER-IN-LAW, don't tell me how to educate my children, I have yours and believe me there is much to claim. DEAR DAUGHTER-IN-LAW, if you don't want me to tell you how to educate my grandchildren, don't leave them in charge of me, take care of them yourself. And remember that you alone look for my son. I have never been offering it to you." [WhatsApp].

"SAD ... WELCOME TO THE XXI CENTURY."

"Where sex is free and love is expensive. Where losing a phone is more painful than losing your virginity."

Where modernization means nudity. Where if you don't drink, smoke or do drugs you are out of fashion.

Where if you do not cheat on your partner, it is because you are not astute or intelligent.

Where bathrooms have been turned into photography studios.

Where lies become realities.

Where pregnancy is more feared than V.I.H.

Where people become toxic when they are told truths or when they resist change.

Where perspectives and clothing decide a person's worth.

Where money is more important than family and friends.

Where there is no Respect ..." [WhatsApp].

"THE DRUNKER AND HIS FRIENDS: shall we take him to his father's house? You're crazy, he will kill him! We better take him to his mother's house so that he sleeps and it will pass." [WhatsApp].

REMARKS: like these brief examples there are many, where differences in behavior of men and women are shown. By not learning that these differences are complementary and not opposite, it is what causes us gender problems.

With positive formative education, there would be a sustainable development, the gains would be permanent due to social stability. History shows us an exacerbated GREED and only by mentally healing we will change paradigms.

"In times of global deception, telling the truth is a revolutionary act." [George Orwell]

"Porn continues to bear much of the weight of poor education of young people when it comes to sexual health issues. Little by little educational projects are being established that aim to integrate affective-sexual education in schools and institutes. What we cannot deny is that access to pornography is easier than ever and we cannot control that they are not exposed to this pornographic content, which does not reflect the reality of a healthy and responsible sexuality."

"It is just as important that this education is given in all schools, hand in hand with professionals and also at home. Parents have the responsibility of providing knowledge and accompanying them in their maturation at all levels, both emotional, affective, intellectual and psychosexual. "[Pornography and Sexual Education in Adolescents, https://albiachpsicologos.es/psicologo-adolescentes-valencia/pornografia-y-educacion -sexual-en-adolescents / $g$ niv42-con963.htm]

REMARKS: With regard to sex education, what is feminism doing about it? Or have they only focused on reporting abuse and protesting and perhaps at times, meaningless complaining. Without drawing attention to sources of pornography and the politicians who allow it with their silence, indifference and apathy. Sexuality is inherent to human being and without controlling the sources of pornography, efforts on sex education will be in vain. some institutions or associations are doing their best to contribute to positive sexuality education; however, in some cases their work has very limited scope due to lack of support from the politicians on duty and mass media.

"Where do we get lost? Postmodernity has dragged us into a wrong paradigm, there are many facilitators, so attractive, that we currently have to make an effort less every day when carrying out our tasks: cars, telephones, dryers, fast foods, microwave ovens, and many more."

"We have sacrificed happiness for pleasure, long term for immediate, consumerism has consumed us."

"Mass media contribute to a large extent in this indolent task, since the heroes so liked by our childhood and youth represent successful characters: Superman, Rambo, Batman, and so many more; Millionaires of all kinds who have a common characteristic: none of them works, they live off the pleasure that they are magically and effortlessly always reaping. This is the image that has been transmitted to collective unconscious of viewers, that pleasure produces happiness, which is false, since pleasure is a natural consequence of happiness, unless that sensation of enjoyment is produced by provoking it with external stimulants such as drugs or alcohol." [Cornejo On Line, HOTMAIL.COM, May 26, 2004]

REMARKS: human being is the most malleable of the animals, due to lack of a robust positive formative education system, technological facilitators and the way in which they are handled in the media, deceive new generations into thinking that this artificial way of life is the real one, it will give you a pleasant life and worst daydreaming of being rich. Leaving nature in the background.

Instead of positively reinforcing the language, mass media distort and degenerate it to appear more "fashionable", under the pretext that it is popular language, reinforcing the negative. They do not assume responsibility, unfortunately they are the ones who set the tone. Resulting in a poorly communicated and misunderstood society. 


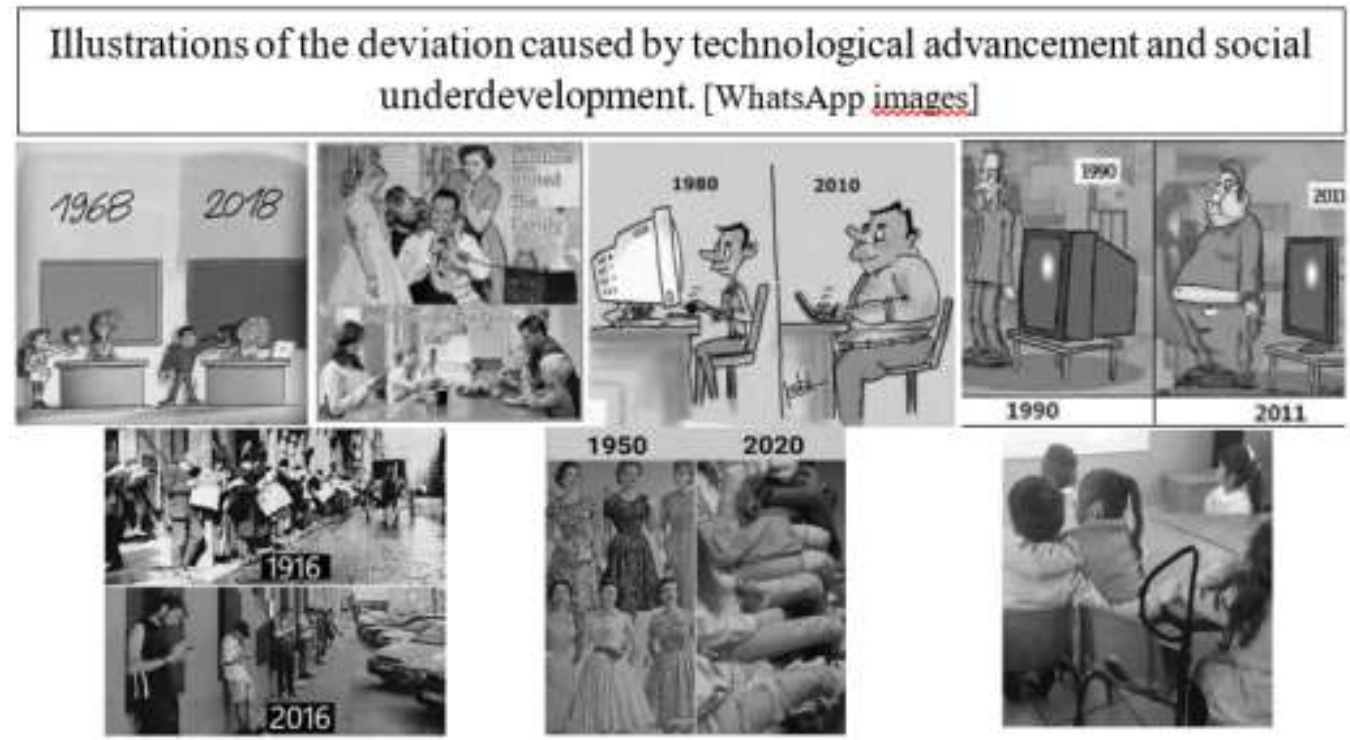

CONCLUSIONS

1. IT WILL BE GOOD THAT IN THE NEXT EVOLUTIONARY STEP OF HUMAN BEING, NATURE AND THE GREAT CREATOR HEAL US MENTALLY

2. FOR FEMINISM TO BE SUCCESSFUL, ALL TYPES OF FEMINISMS MUST COME TOGETHER, TO ELIMINATE HARASSMENT, ABORTION, HEMBRISM, MACHISMO, MISANDRY, PORNOGRAPHY AND PROSTITUTION, A ROBUST POSITIVE FORMATIVE EDUCATION MUST BE IMPLEMENTED, FROM THE HOME TO EDUCATIONAL INSTITUTIONS, SUPPORTED BY THE MEDIA, OTHERWISE IT WILL BE LEFT IN A STERILE EFFORT.

3. FEMINIST MOVEMENT IS AN EFFORT THAT TRIES TO SOLVE ONE OF THE ERRONEOUS ATTITUDES, OF GENDER EQUALITY; HOWEVER, IT MUST DO SO WITH CONSENSUS OF MAN, SO THAT THE SOLUTION IS EQUITABLE, IF IT IS WRONG, IT WILL EXACERBATE EXISTING PROBLEMS.

4. HARMFUL ATTITUDES OF INDIVIDUALISM, CLASSISM, MACHISMO AND ARROGANCE OF MEN, AS WELL AS DEBAUCHERY AND EMBOLDENING OF WOMEN ARE CLEARLY SEEN IN SOME SONGS AND MUSIC VIDEOS. AND INSTEAD OF DISAPPROVED IT, SOME ADMIRE IT.

5. IF MAN NEEDS MORE THAN WOMAN TO TAKE CARE OF HIS INSTINCTS, WITH THE DEBAUCHERY IN WOMAN'S DRESS, IT TEMPTS MAN, EVEN IF WOMAN ARGUES OTHERWISE AND SAYS THAT THEY HAVE THE "RIGHT" TO DRESS AS THEY WANT. BOTH NEED A POSITIVE FORMATIVE EDUCATION.

6. ALARMING NUMBERS OF ABORTIONS SHOW A DEBAUCHERY AND IRRESPONSIBILITY, BOTH OF WOMEN AND MEN IN SEXUAL RELATIONS.

7. IF WE ARE SO BRAVE TO CUT A LIFE BY ABORTION, WE SHOULD ALSO BE SO BRAVE FOR MAN TO HAVE A VASECTOMY AND WOMAN TO BLOCK THE FALLOPIAN TUBES.

8. A VERY COMMON ATTITUDE OF WOMEN IS THAT WHEN HE DEMANDS SOMETHING FROM HER, SHE REFUSES TO DIALOGUE, REMAINS SILENT AND IS OFFENDED.

9. MISANDRIC WOMAN, SHE COULD UNLOAD HER ANGER AND GIVE AN INAPPROPRIATE TREATMENT TO HER BOYS. THIS DOES NOT EXEMPT THE MALE CHAUVINIST FROM INAPPROPRIATE TREATMENT TO THE FAMILY.

10. WOMAN BOASTS HER ABILITY TO "REMEMBER THINGS THAT HAVE NOT YET HAPPENED". THIS IN NO WAY CONTRIBUTES TO A GOOD RELATIONSHIP WITH MAN.

11. NATURE ENDOWED BOTH MALE AND FEMALE WITH SPECIFIC CHARACTERISTICS TO SURVIVE AS A WHOLE. WE MUST EDUCATE OURSELVES TO UNDERSTAND THOSE DIFFERENCES. BOTH ATTITUDES ARE NECESSARY AND COMPLEMENTARY. NATURE DOES NOT MAKE MISTAKES.

12. THE FACT THAT WOMAN TALKS A LOT IS A NATURAL CHARACTERISTIC THAT SHOULD ONLY BE REDIRECTED CORRECTLY AND POSITIVELY THROUGH A POSITIVE FORMATIVE EDUCATION.

13. HUMAN BEING HAS FORGOTTEN TO DEFINE THE NATURAL RULES OF SUBSISTENCE; AS AN ANIMAL, HE BELIEVES HIMSELF SUPERIOR TO ANY OTHER ANIMAL AND SOMETIMES TO OTHER COLORS OF SKIN. 
14. EACH GROUP, SECTOR OF SOCIETY OR COUNTRY, ARE CREATING RULES AND REGULATIONS AT THEIR CONVENIENCE, CAUSING TENSIONS, FORGETTING AND MOVING FURTHER AWAY FROM LAWS OF NATURE.

15. ATTITUDES THAT MUST BE RESOLVED WITH COMMON SENSE AND EDUCATION, WHICH ARE INTENDED TO BE RESOLVED WITH LAWS, WILL BE A PALLIATIVE SOLUTION AND WILL CREATE A SOCIETY WITHOUT COMMON SENSE.

16. IF COMMERCIAL TELEVISION PARTICIPATED IN POSITIVE FORMATIVE EDUCATION, CURRENT COMMERCIALS WOULD NOT BREAK THROUGH EMOTION. ADVERTISING THE PRODUCTS IS NECESSARY AND THEY WILL SELL, AS PEOPLE NEED THE PRODUCTS. MANIPULATION IS THE WICKED THING.

17. FEMINISTS ARE BEHAVING WITH VIOLENCE SIMILAR TO WHAT THEY CLAIM TO FIGHT. THEY ARE FIGHTING VIOLENCE WITH VIOLENCE.

18. UNDOUBTEDLY, MACHO ATTITUDES SHOULD BE ELIMINATED, AS WELL AS HEMBRIST ATTITUDES THAT GROW MORE EVERY DAY. BUT ONLY MACHISMO HAS BEEN DEMONIZED, TRYING TO ELIMINATE IT WITH PUNITIVE AND INQUISITIVE LAWS. SOME PSEUDO FEMINISTS BELIEVE THAT THEY WERE GIVEN THE RIGHT TO MISTREAT MEN AND THEY CANNOT EVEN DEFEND THEMSELVES, SOMETIMES ANY REACTION FROM MEN IS ACCUSED OF VIOLENCE AGAINST WOMEN GENDER. AS LONG AS THE FACTORS THAT FEED THEM DO NOT CHANGE, THE PROBLEM WILL PREVAIL. ANY SITUATION OF IMBALANCE WILL RETURN TO ITS NORMAL POINT, REGARDLESS OF CONSEQUENCES.

19. ATTITUDES OF REVENGE, GENERATED BY MISINTERPRETATION OF FEMINISM OR VESTED INTERESTS, PROVOKE DEBAUCHERY, EMBOLDENED AND HEMBRISM.

20. IT IS COMMENDABLE THAT WOMEN DEFINE THEIR OWN FEMININE CULTURE AND ESTABLISHES A GENEALOGY THAT IDENTIFIES THEM; WITHIN LAWS OF NATURE.

1. \#MILAGRO

\section{REFERENCES}

2. 4ODÍAS PORLAVIDA

3. ANÓNIMO, POR HOMBRES

4. ANÓNIMO, POR MUJERES

5. ANTROPOECOLOGÍA, LEONEL CHACÓN ANCHONDO.

6. COMENTARIO, MLCHR, 2002 AD.

7. CORNEJO ON LINE, HOTMAIL.COM, 26 DE MAYO DEL 2004

8. DANICXA PAJUELO DURAND

9. DEFINICIOYQUE.ES

10. DICHOS POR UNA MUJER QUE NACIÓ EN 1916-2012 AD.

11. EL MITO DE LA MUJER, GENARO CHIC GARCÍA, HTTPS:// WWW.ACADEMIA.EDU/37102787

12. ELLIBREPENSADOR.COM

13. ELPUCLITICO.CL

14. ESTADÍSTICAS DEL DEPARTAMENTO DE SALUD DEL ESTADO DE FLORIDA

15. FACEBOOK ORGULOSADESERMUJER

16. FOTOS DE REDES SOCIALES

17. GEORGE ORWELL

18. GRUPO DE MUJERESIXCHEL.BLOGSPOT.COM

19. HTTP://WWW.ABORTOLEGAL.COM.AR/LA-ONU-SE-EXPIDE-EN-FAVOR-DEL-ABORTOVOLUNTARIO/

20. HTTP://WWW.CDP.UDL.CAT /COEDUCACIO/INDEX. PHP/ES/AUTORIDAD-Y-GENEALOGIAFEMENINAS

21. HTTP://WWW.ENTENDER-AL-HOMBRE.NET/INDEX.PHP/ENTENDER-A-LOS-HOMBRES-COMO-

PIENSAN-Y-SIENTEN/LOS-HOMBRES-TIENEN-MIEDO-DE-MUJERES-FUERTES,CHRISTIAN SANDER

22. HTTPS://ANDRESSOLO.WORDPRESS.COM/2015/12/01/HEMBRISMO-O-LLAMALE-COMOQUIERAS/

23. HTTPS://AYUDAENACCION.ORG/ONG/BLOG/MUJER/

EMPODERAMIENTO-FEMENINO-

INFANCIA/, BEGOÑA RODRÍGUEZ PECINO

24. HTTPS://DEFINICION.DE/PARIDAD/

25. HTTPS://ES.WIKIPEDIA.ORG/WIKI/FEMINICIDIO

26. HTTPS://HISTORIASDEMODA.COM/EL-VESTIDO-LA-PRENDA-QUE-HABLA-POR-LAS-MUJERES/,

2016-02-26 AGUSTINA ANDUJAR CAVALLO DESTACADOS, HISTORIAS DE MODA 0

27. HTTPS://ISMORBO.COM/QUE-SIGNIFICA-EL-TERMINO-KAREN/ 
28. HTTPS://MX.SEARCH.YAHOO.COM/SEARCH?FR=MCAFEE\&TYPE=E210MX91215G0\&P=

DEFINICI\%C3\%B3 N+DE+ACOSO

29. HTTPS://PSICOLOGIAYMENTE.COM/ CLÍNICA /MIEDO-A-LAS-MUJERES-GINEFOBIA

30. HTTPS://WW.EVANGELICODIGITAL.COM/MUNDO/11184/MAS-DE-42-MILLONES-DE-ABORTOS-

SE-REALIZAN-EN-EL-MUNDO-EN-2019

31. HTTPS://WWW.ANIMALPOLITICO.COM/2020/03/MUJERES-MARCHA-8M-CDMX-PROTESTA-

MACHISTMO/

32. HTTPS://WWW.CHICAGOTRIBUNE.COM/HOY/CT-HOY-FEMINICIDIO-PLAGA-MUNDIAL-

PERSISTENTE-20191119-OAASWCWJZFBOHF2LLVZA4DINLE-STORY.HTML

33. HTTPS://WWW.ELPERIODICO.COM/ES/SOCIEDAD/20180529/MUJER-CUERPO-DESNUDO-REDES-

SOCIALES-6844963 MAMEN HIDALGO, MADRID, 29/05/2018

34. HTTPS://WWW.FACEBOOK.COM/GROUPS/NOSTALGIASCDJUAREZYEL PASO/?...

35. HTTPS://WWW.GOB.MX/INMUJERES/ARTICULOS/LA-PARIDAD-DE-GENERO-UN-ASUNTO-DE-

IGUALDAD-Y-DE-JUSTICIA? IDIOM=ES

36. HTTPS://WWW.GOOGLE.COM /SEARCH? DEFINICION+DE+ABORTO+OMS\&OQ =DEFINICIÓN

$+\mathrm{DE}+\mathrm{ABORTO} \& \mathrm{GS}$

37. HTTPS://WWW.GOOGLE.COM/SEARCH?Q=CUANDO+EMPIEZA+A+LATIR+CORAZON+DEL+FETO $\&$ RLZ $=1 \mathrm{C} 1 \mathrm{CHBF}$

38. HTTPS://WWW.LAVIDALUCIDA.COM/POR-QUE-LOS-HOMBRES-TIENEN-MIEDO-DE-LAS-

MUJERES-INTELIGENTES.HTML, DAYERLIN SOSA LÓPEZ

39. HTTPS://WWW.MUYINTERESANTE.ES/CULTURA/ FOTOS/TIPOS-DE-FEMINISMO/1

40. HTTPS://WWW.SERPADRES.ES/EMBARAZO/TU-BEBE/VIDEO/LOS-PRIMEROS-LATIDOS-DEL-

CORAZON-DEL-FETO\#: :TEXT

41. HTTPS://WWW.SIGNIFICADOS. COM/HEMBRISMO/

42. HTTPS://WWW.SIGNIFICADOS.COM/FEMINISMO/

43. HTTPS://WWW.SIGNIFICADOS.COM/MACHISMO/ 4 DE ENERO DE 2021

44. HTTPS://WWW.YOUTUBE.COM/WATCH? V =Q5MH9FL9PX8

45. HTTPS://WWW.YOUTUBE.COM/WATCH?V=0CPJIZRBLWC, MINUTO 24 VIDEO: SER MUJER JUDÍA ORTODOXA, GUILY WILUZANSKI

46. HTTPS://WWW.YOUTUBE.COM/WATCH?V=AP0EUIOK-HI\&LIST=PL5PYK0GKYG_8

UFUOOWCGXJX7SQEMVXDAU

47. HTTPS://WWW.YOUTUBE.COM/WATCH?V=B_UR-VUOCOS,

48. HTTPS://YOUTU.BE/Q5MH9FL9PX8?T=19

49. JOHN MACARTHUR

50. KATIA MONTEAGUDO, YAHOO NOTICIAS 4 DE NOVIEMBRE DE 2019

51. LAREALIDADESCONDIDA.WORDPRESS.COM

52. MADRE TERESA DE CALCUTA

53. MARÍA FÉLIX

54. MÓNICA MANCERO ACOSTA, EDITORIALISTAS, ENERO 2014

55. OMS. ABORTO PROVOCADO. INFORME DE UN GRUPO CIENTÍFICO. SERIE DE INFORMES TÉCNICOS N623, GINEBRA,1978.

56. PLAZAABIERTA.COM

57. PORNOGRAFÍA Y EDUCACIÓN AFECTIVO-SEXUAL, TERESA FACAL FONDO, CARLOS ROSÓN VARELA, LLUÍS BALLESTER BRAGE, HTTPS://OCTAEDRO.COM/LIBRO

58. PORNOGRAFÍA Y EDUCACIÓN SEXUAL EN ADOLESCENTES, HTTPS://ALBIACHPSICOLOGOS.ES /PSICOLOGO-ADOLESCENTES-VALENCIA/PORNOGRAFIA-Y-EDUCACION-SEXUAL-EN-

ADOLESCENTES/G MX-NIV42-CON963.HTM

59. REAL ACADEMIA ESPAÑOLA (RAE), HTTPS://MX.SEARCH.YAHOO.COM/SEARCH;YLT=AWRG EA7SSMFDBMEA10DD8QT

60. TANIA, POR EL \& ELLA | EL ELLA - MIÉRCOLES, 23 NOV 2011

61. TITO LIVIO (59 A.C. - 17 D. C), HISTORIADOR ROMANO

62. TRAVELERS DREAMS

63. WHATSAPP IMAGINES

64. WHATSAPP VIDEOS

65. WWW.FACEBOOK.COM/PERSONHOODEDUCATION 
978-620-2-12192-7 Spanish

978-620-0-96012-2 Russian

978-620-0-96011-5 German

978-620-0-96019-1 Dutch

978-613-9-85828-6 English

978-620-0-96013-9 French

978-620-0-96017-7 Italian

978-620-0-96014-6 Portuguese

978-620-0-96021-4 